\title{
AGRICULTURAL TREATISES IN EURASIA BEFORE CA. I500:THE ICEBERG METHOD, A SURVEY, AND A GRAND HYPOTHESIS
}

\author{
JANKEN MYRDAL
}

FOR MORE THAN two thousand years, agricultural treatises have been an unbroken literary genre throughout Eurasia (including North Africa). These texts are crucial for our understanding of farming practices, but also for our understanding of intellectual history: the history of pragmatic knowledge, in particular the story of how humans collected and shared intelligence for manipulating the material world. ${ }^{1}$ The survey presented in this article enables a new view of premodern global history by recovering the spread of information about agricultural praxis, revealing patterns of regional difference but also hitherto hidden connectivities within Eurasia and the deep roots of modern processes. ${ }^{2}$ To take but one example, a global approach to the study of agricultural treatises reveals the situated forms of practical knowledge underlying the reasons for the choice of specific draught animals-a crucial question for most farmers. In England, Walter of Henley's AngloNorman French treatise on husbandry (ca. 1285) compared horses to oxen and claimed horses to be faster but more costly to feed and house; moreover, when the horse became old, only its skin could be used (eating horsemeat was prohibited), but an ox could be fattened to slaughter. ${ }^{3}$ In China, the choice was between water buffalo and oxen. According to the treatise of Sung Ying-hsing, published in 1637, the buffalo is twice as strong as the ox, but it needs twice as much care because it has to be housed during the winter and provided with a pond for bathing in the summer. ${ }^{4}$ By reading these texts comparatively, we uncover evidence about practical decision-making in both locales but also discern the similar intellectual arguments that undergirded these decisions.

While agricultural historians refer to these treatises, ${ }^{5}$ a comparative and comprehensive analysis of them has never before been attempted. This article aims to fill this empirical gap by surveying all the major Eurasian agricultural treatises

I Sigaut, Comment, 20, 24.

2 Symes, "Introducing the Medieval Globe."

3 Oschinsky, Walter of Henley, 319.

4 Sung, Chinese Technology, 8.

5 For example, Zadoks, Crop Protection. 
produced in the premodern era. The results will be useful for historians of any world region interested in agrarian topics or the codification and circulation of practical knowledge. It also offers a rich data set useful for comparative histories of regions within and beyond the Eurasian landmass because it surveys the total number of major treatises, their contents, their length, their surviving manuscripts, and their degree of influence (see Appendix 1).

This survey is also closely tied to scholarly discussions about literacy, since it concerns the conversion of orally transmitted knowledge into written texts. And yet practical handbooks of this kind have not usually been included in such research. ${ }^{6}$ Jack Goody has mentioned agricultural writing but assumed that it spread new knowledge, ${ }^{7}$ a conclusion that I have found to be mainly incorrect and also problematic, because it overlooks the ways in which agricultural knowledge was transformed into literary texts. Research on "pragmatic literacy" is a related area of research, but again, not much attention has been paid to agricultural treatises. Definitions of pragmatic literacy can be inclusive ${ }^{8}$ or restricted to administrative literature and record-keeping. ${ }^{9}$ Agricultural treatises could be seen as a part of this genre, if broadly defined, and research on pragmatic literature has certainly shown that such prosaic texts can be analyzed as documents of intellectual history.

The process of transforming oral or embodied forms of knowledge into writing is genre-specific, best captured by the German term Literaturfähig, "something worthy of committing to writing." ${ }^{10}$ (The English equivalent, "literacy-suitability," is rather inelegant.) This genre specificity means that discoveries about the oral composition of epic poetry, which have been so groundbreaking for understanding the relationship between orality and literacy, cannot be taken as model for all other genres. ${ }^{11}$ For instance, the documentation of theatrical plays, which overlaps with both practical manuals and literary texts, is specific to the circumstances in which a given play is committed to parchment and the reasons for the creation of a written record. ${ }^{12}$

So what about treatises devoted to farming? In agriculture, skills are transmitted bodily and often tacitly learned by mimicking and testing. Today, we still learn much orally and through imitation, but originally all complex activities

6 Cf. Mostert, Medieval Communication.

7 Goody, The Logic of Writing, 84-85.

8 Mostert, Medieval Communication, 13; Meier, “Fourteen Years," 25.

9 Britnell, "Pragmatic Literacy," 3-4.

10 See Pollock, Language of the Gods, 439-40.

I I Cf. Ong, Orality and Literacy.

12 Symes, "Appearance of Early Vernacular Plays." 
were taught in this way. By contrast, a written text structures knowledge in a linear fashion; a book about farming might have chapters on crops, irrigation, cultivation, and so on, which present information differently from how such knowledge is actually taught in the field. The transformation of practical intelligence into a textual form involves a fundamental restructuring of how to think about agriculture.

Would this imply that agricultural treatises contributed to a more structured way of thinking about farming? These treatises had few readers and, in many regions without surviving treatises, agriculture developed in the same direction as in those that did produce treatises. I suggest, instead, an inverted hypothesis. If a systemic approach did become more prevalent in agriculture, it facilitated the conceptualization of praxis as Literaturfähig. Thus, agricultural treatises came into being as a result of prior and concurrent developments. This could also explain why the practice of writing treatises emerged independently and simultaneously in eastern and western Eurasia. To prove such a grand hypothesis, we would need to explore all the major changes in agriculture across Eurasia, which is not the aim of this article. I will, however, tentatively return to this grand hypothesis in my conclusion.

\section{Interpretations of Agricultural Treatises: Bias and Relativism}

A peril which haunts global history is the temptation to see it as a contest among different nations and cultures. But every culture creates its own "miracle" in interaction with others. ${ }^{13}$ Furthermore, advances in agriculture began without books and treatises. To use the existence of agricultural treatises as the sign of a higher level of ingenuity is therefore a dangerous simplification. For example, China has a strong tradition of producing agricultural treatises and, in 2012, Chinese agronomists asserted that African agriculture has much to learn from China and devoted the first chapter of Agricultural Development in China and Africa: A Comparative Analysis to ancient Chinese agricultural treatises in order to argue for the superiority of the Chinese tradition. ${ }^{14}$ Another example of treatises being used to pursue an ideological agenda has surfaced in the discussion around the emergence of Islam and rates of technological change: Andrew Watson argued that a technological leap occurred in the Islamicate world before and around 1000, a theory which was later criticized by Michael Decker. ${ }^{15}$ Both used agricultural treatises as their main sources. Academic debates are necessary, but this one

13 Thapar, The Penguin History, 18.

14 Li et al., Agricultural Development, 58-61.

15 Watson, Agricultural Innovation; Decker, Tilling the Hateful Earth. 
opened a space for diatribes against Muslims as being incapable of contributing to historical progress. For instance, the Wikipedia article on "Arab Agricultural Revolution" received more than a hundred posts a short time after Decker opened the discussion. ${ }^{16}$

With this in mind, let us consider another charged discussion, this one about the emergence of a knowledge-based society in modern Europe. The economic historian Jan Luiten van Zanden has argued that the production of literature can be used as an indicator for the growth of human capital or, more precisely, for the development of the knowledge that promotes economic productivity. ${ }^{17}$ Together with collaborators, he constructed a very useful database of the total number of all kinds of manuscripts copied in Europe until around 1500. Thereafter, when print had largely replaced handwriting, they estimated the total number of printed books in production. This enabled a comparison with data from western Asia, India, China, and Japan, which indicated that Europe in the later Middle Ages had a faster increase in textual production than other regions in Eurasia. Van Zanden also demonstrated a correlation between increased book production in the eighteenth century and other economic variables. ${ }^{18}$ However, correlations do not immediately imply causation: in this case, it is problematic to credit written texts as agents of economic expansion in a preindustrial society when they were actually read by so very few. Joel Mokyr, who also used agricultural literature to study the emergence of a knowledge-based society, has shown that knowledge conveyed in books and pamphlets did not have much impact on technological praxis until after the midnineteenth century. Ordinary farmers simply did not read these books, and only a "small sliver of the agricultural sector" was directly affected, though knowledge could have spread through other channels. ${ }^{19}$

In a study of agricultural literature produced in the eighteenth century, I counted the number of books printed in English-speaking regions (England, Scotland, Ireland, North America) and all texts (in books and journals) from Scandinavia. I found that a rapid increase in the production of such texts is evident after the middle of the eighteenth century, and yet they had a restricted influence on agricultural practice because so few copies were in circulation. This was a period when cultivated areas were expanding and technology was advancing; so what was the relationship between agricultural change and the expanding literature?

16 Wikipedia. "Arab Agricultural Revolution," https://en.wikipedia.org/wiki/Arab_ Agricultural_Revolution.

17 van Zanden, The Long Road.

18 Baten and van Zanden, "Book Production."

19 Mokyr, The Enlightened Economy, 183-89. 
By tracing the topics being discussed at certain periods of time, such as the use of harrows or crop rotation, I could show a concurrence between the literature and what was happening on the ground: new knowledge was being tested and replicated in praxis and also communicated in texts. Hence, the changing content of the literature was caused by changing agricultural practice: the reverse of what had been assumed. ${ }^{20}$ To be sure, literature had some practical effects in the long run because intellectuals had a keen interest in describing and endorsing the innovations that were transforming the countryside-but again, the interaction between text and practice was complex, and literature was only one, and not the most important, of the factors contributing to change. Nor was the transformation of agriculture merely a European phenomenon: most of Eurasia went through a period of rapid agrarian change in the nineteenth century. If literature is recognized as a response to the quickening expansion of agricultural production and technological change, this also implies that the expanded production of agricultural treatises can be analyzed in a less Eurocentric way. Moreover, as I will show in this article, the growth in the publication of these treatises had a very long and pan-Eurasian prehistory.

\section{The "Iceberg Method": An Approach to the Problem of Analyzing Comparative Evidence in Global History}

Normally, global surveys are based on secondary sources, and although I have read quite a few of the treatises I analyze here, I cannot claim to have worked with them as primary sources in all of their original languages. My searches have accordingly been made with the help of libraries with open stacks, literature mentioned in the scholarly overviews, and, of course, internet resources to find and evaluate secondary sources (including translations). ${ }^{21}$ Now, if several scholars with expert knowledge of specific regions and bodies of literature worked together on a joint project, we would get a deeper knowledge of them, but not necessarily a clearer synthesis. $^{22}$

Comparability is of paramount importance in global history. Kenneth Pomeranz has argued that any regions compared should be of equal size, meaning

20 Myrdal, "Agricultural Literature," which is a companion to the present article; together, they form a history of agricultural literature before the modern period.

2I On secondary literature as a source, see Myrdal, "On Source Criticism." Theda Skocpol offers a short but insightful discussion on this as a methodological problem: "Emerging Agendas," 382-83.

22 Lieberman, Strange Parallels, xx, on the advantages of a one-person project. 
that England, for instance, cannot be compared with all of China. ${ }^{23}$ The same is true for specific subjects; entities should be comparable. Two pitfalls in particular must be avoided. One is the "cherry-picking" of evidence to support an argument, by which anything can be "proven." This method is depressingly common in global historiography. The second, if more respectable, pitfall is to assemble as much evidence as possible. The risk is that the quantity overwhelms the significance, and this often leads to overestimations of Europe's importance. To avoid these pitfalls, I have suggested a new critical approach which focuses on the most salient and visible manifestations of a phenomenon. ${ }^{24}$ The approach, here labelled "the Iceberg Method," posits that the most prominent extant instances of a historical trend indicate the existence of lost or submerged sources, agents, or events. This method is not intended to replace detailed research based on primary sources; quite the contrary, since it can help to identify areas where more primary research is needed. In the case of agricultural treatises, the most salient texts reflect and communicate substantial knowledge of agricultural practice, and they also have a certain demonstrable long-term impact.

In this study, I have also used the length of a treatise as a measurement for estimating its significance, but with the recognition that word-counting is a coarse measurement, especially when comparing different languages and traditions. For example, Columella's books on agriculture, produced in the first century CE, comprise 120,000 words in Latin and swell to about 210,000 words in English translation. In classical Chinese, the surviving parts of the oldest known treatise, written by Fan Sheng-Chih (Fanshengzhi) in the first century BCE, consist of about 3,700 Chinese characters, or 5,700 words in English. At the same time, I have excluded from the Appendix and Table 1 treatises of fewer than two to three thousand words. However, I do include shorter extant works in this analysis: for instance, a seemingly important book on ploughs written in China around 880 CE, which comprises only about 700 characters. ${ }^{25}$ Works preserved only in later translations have been dated to the era in which they were originally composed, but they are not included in the table. In addition, all word counts are based on translations into modern English or other major European languages, for comparability, with the exception of one Persian treatise and most of the classical Chinese treatises. With respect to the latter, note that the number of words in English translation is normally 50-60 percent higher than the number of Chinese characters.

23 Pomeranz, The Great Divergence, 7.

24 Myrdal, “On Source Criticism," 65-70.

25 Deng, Development versus Stagnation, 75-76. 


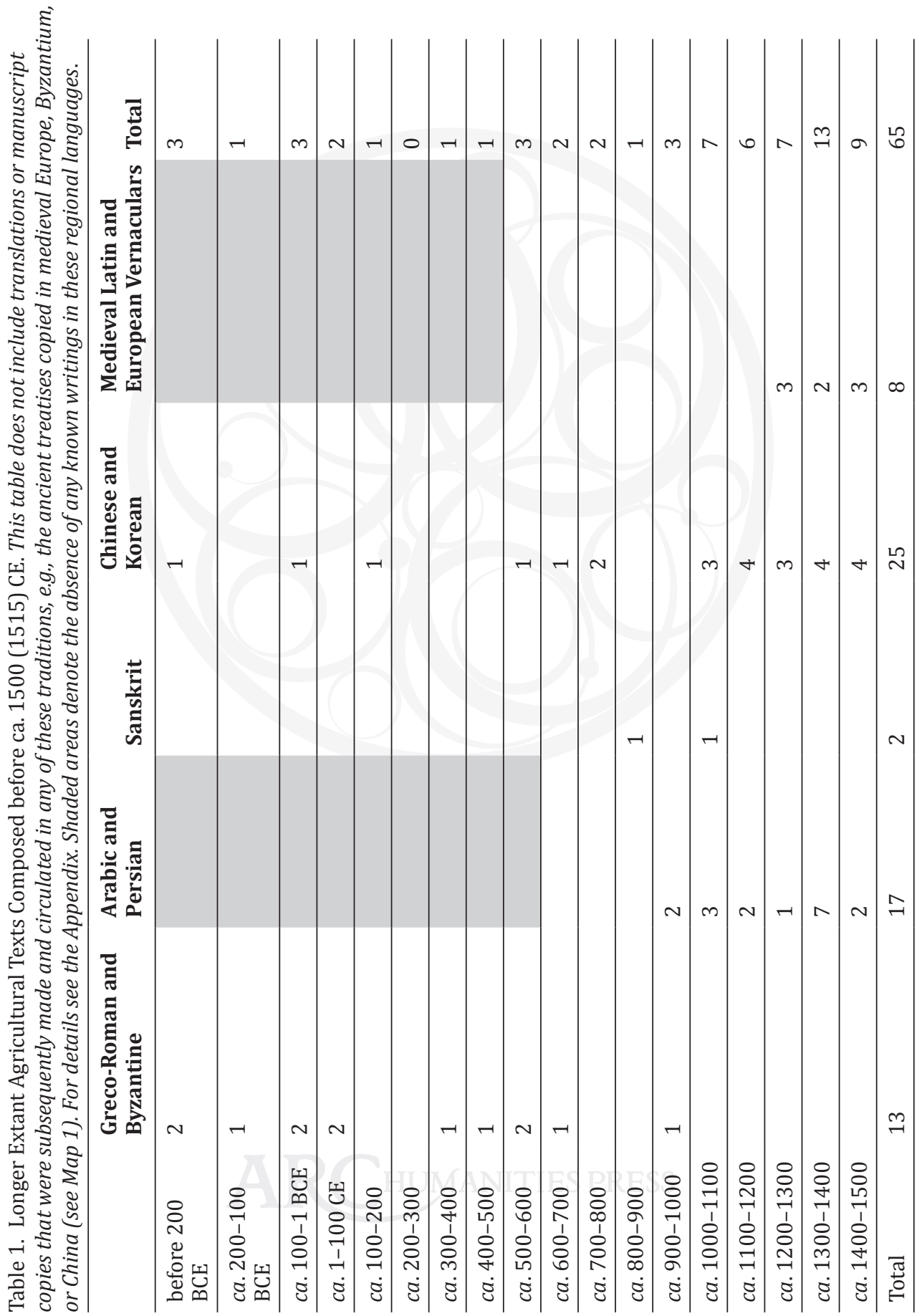


I have not, moreover, counted all early translations, because it would be almost impossible to get an accurate reckoning of them, especially since many have eluded the available surveys. To take an example from my own research, Columella's work was translated into Swedish in the early sixteenth century, a fact well known in Sweden but never mentioned in any European overview. That said, I would welcome a thorough survey of these translations because they are extremely important for understanding how knowledge was transmitted.

This analysis, while comprehensive of all known agricultural treatises, excludes equine literature and Indian books on elephants, as well as botanical and medical works - though of course these specific genres often contain information about draught animals and plants. Encyclopedic works have been included if they contain substantial sections on agriculture.

As for the number of extant manuscripts and manuscript variants, this data has not been assembled in a systematic manner for all parts of Eurasia. The survival of a text and the extent of its diffusion are two different but related things. Extant copies are often of a much later date than the original composition. Moreover, the number of extant manuscripts also depends on different practices of publication, dissemination, and preservation in libraries and archives. Climate, as in southern India, or the efficiency of a given bureaucracy, as in imperial China (where outdated accounts were purged, or otherwise the pile of documents would have been overwhelming), are also factors which could dramatically diminish the survival rate of texts. The very different medieval European practice of archiving even obsolete matter also impacts the survival rate of pragmatic texts. ${ }^{26}$

Finally, the relationship between the treatises and agricultural praxis is of prime importance, and often discussed in different editions. A closer examination using a wide range of sources is of prime importance. ${ }^{27}$ Here, my comparative analysis of the treatises' contents is intended to gauge the extent to which they mirror actual regional conditions, partly following methods employed by Karl Butzer and Gang Deng. ${ }^{28}$

26 Britnell, "Pragmatic Literacy," 24.

27 Together with Alexandra Sapoznik, I am working on a comparison of medieval treatises from thirteenth-century England and the contemporary manorial accounts. See Myrdal and Sapoznik, "Technology, Labour."

28 Butzer, "Islamic Traditions," 18-19; Deng, Development versus Stagnation, 62-73, 78, 82, 87,93 . I prefer proportion to the more precise percentage, as calculations of content include a number of estimations. 


\section{For Comparison: Measuring the Early Modern Expansion of Agricultural Literature}

To better understand the scale at which premodern agricultural treatises were produced, it is helpful to begin with what we know about the production of agricultural treatises in the early modern era, with the advent of print. After ca. 1500 , books about agriculture were printed continuously in western Europe's major vernaculars from the first half of the sixteenth century onward. ${ }^{29}$ These treatises also circulated in neighbouring regions, because it took some time before they began to be composed and published in the periphery. For example, both Spanish and French treatises circulated in Portugal from the sixteenth to the eighteenth centuries. ${ }^{30}$ In Scandinavia, agricultural treatises were not printed until the end of the seventeenth century. ${ }^{31}$

A database of printed books in English, the English Short Title Catalogue (ESTC), shows that, on average, one text/book about agriculture was published annually in England from the early sixteenth to the early eighteenth century, with evidence of a gradual increase: see Figure 1. The curve is exaggerated at the outset,

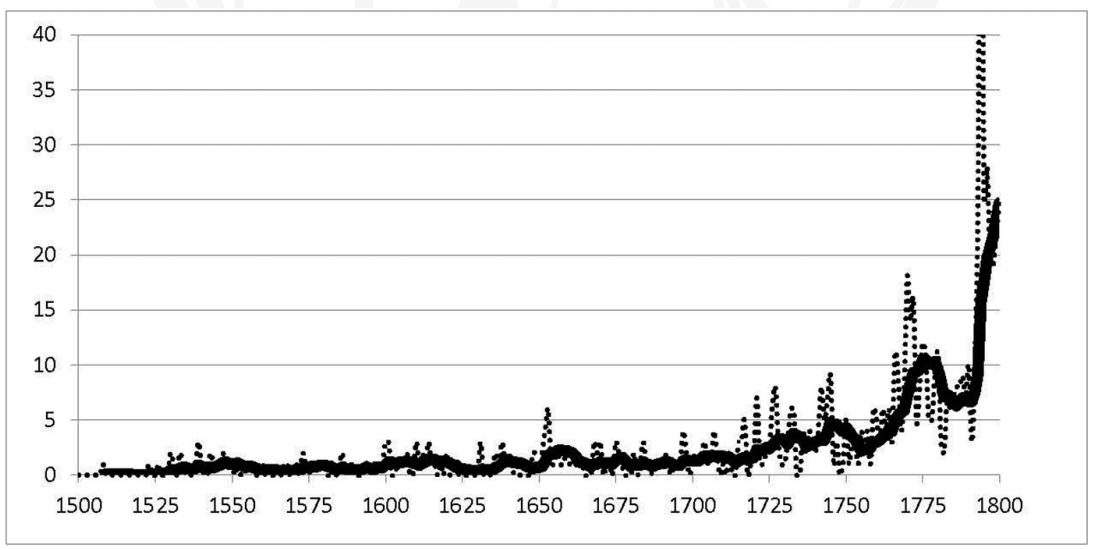

Figure 1. Diagram of Publications on Agriculture Printed in England, 1500-1800.

The dotted line represents the number of published titles per annum and the boldface line represents a ten-year running average.

Source: English Short Title Catalogue (ESTC).

Note that for the period after 1641, only books have been counted.

29 Fussell, Classical Tradition; Beutler, "Un Chapitre de la sensibilité."

30 Rodrigues, "Gardening Knowledge."

31 Myrdal, "Agricultural Treatises." 
however, because the ESTC includes every kind of printed matter for the period pre-1641, but includes only books for the following period..$^{32}$ The diagram is based on the categorizations supplied by compilers of the database, so it can easily be checked, but I counted every title in the catalogue and found only slightly higher numbers that follow this curve fairly well. I discuss this eighteenth-century data in more detail elsewhere. ${ }^{33}$

A similar trend is also evident in other countries, especially in China (less so in the Islamic countries, see below). In China, the production of new titles also increased during the early modern period. According to data compiled by Deng, the average number produced annually was 0.5 during the Ming dynasty (1368-1644), rising to 0.7 in the Qing dynasty (1644-1911), ${ }^{34}$ amounting to an increase of five to seven books per decade. Thus, China seems to have produced agricultural literature at the same rate as England. According to the guidelines for regional comparison laid out by Pomeranz noted above, Europe as a whole appears to have a higher rate of production than China. This can be partly explained by the greater variety of languages in which European treatises were written and the more decentralized pattern of their publication: hence, Europe from the sixteenth century onward increasingly took a dominant position in the production of agricultural treatises.

\section{The Long History of Agricultural Writing: A Summary of the Major Traditions}

The earliest known written work devoted to agricultural practice is Sumerian, composed around 1800 BCE. It comprises fewer than a thousand words in an English translation, and is much shorter than most of the works mentioned below. ${ }^{35}$ Judging from the number of tablets and fragments preserved, it must have been quite widespread in Mesopotamia for about a hundred years, until around $1700 \mathrm{BCE}$, when it sank into oblivion; there is no link to later agricultural treatises. Sometimes called an almanac, the text itself is labelled an "instruction" and speaks

32 McKitterick, "Bibliography, Population," 84. For an estimation of annual book production in England 1475-1700, see Barnard and Bell, "Statistical Tables," 779-85, which shows a gradual increase during the sixteenth and early seventeenth century. The entries in the ESTC do not state the number of pages for each text.

33 Myrdal, "Agricultural Literature."

34 Deng, Development versus Stagnation, 28.

35 Civil, The Farmer's Instruction, 28-33, with an edition of a version from about 1730 BCE (some 983 words in the English translation) and a list of all variants together with other related texts. 
only to the cultivation of cereal crops. It does not, therefore, include a number of the elements associated with later almanacs.

The great and unbroken traditions of Eurasian agricultural treatises began about two and a half thousand years ago. Table 1 shows the number of extant (longer) treatises and Map 1 allows us to see patterns of diffusion and influence among regions. As I explained above, while I have not made a comprehensive survey of all translations, my analysis of the relevant scholarship has enabled this rough depiction of how treatises were disseminated. In the table, I have sorted the extant treatises into their broad cultural spheres, characterized by linguistic, political, religious, and economic affiliations. In the Islamicate world, for example, the map enables us to see that the locus of book production shifted from western Asia and North Africa to al-Andalus (Muslim Spain) and then back to western Asia, to be continued in Persia and reflecting larger historical trends. ${ }^{36}$

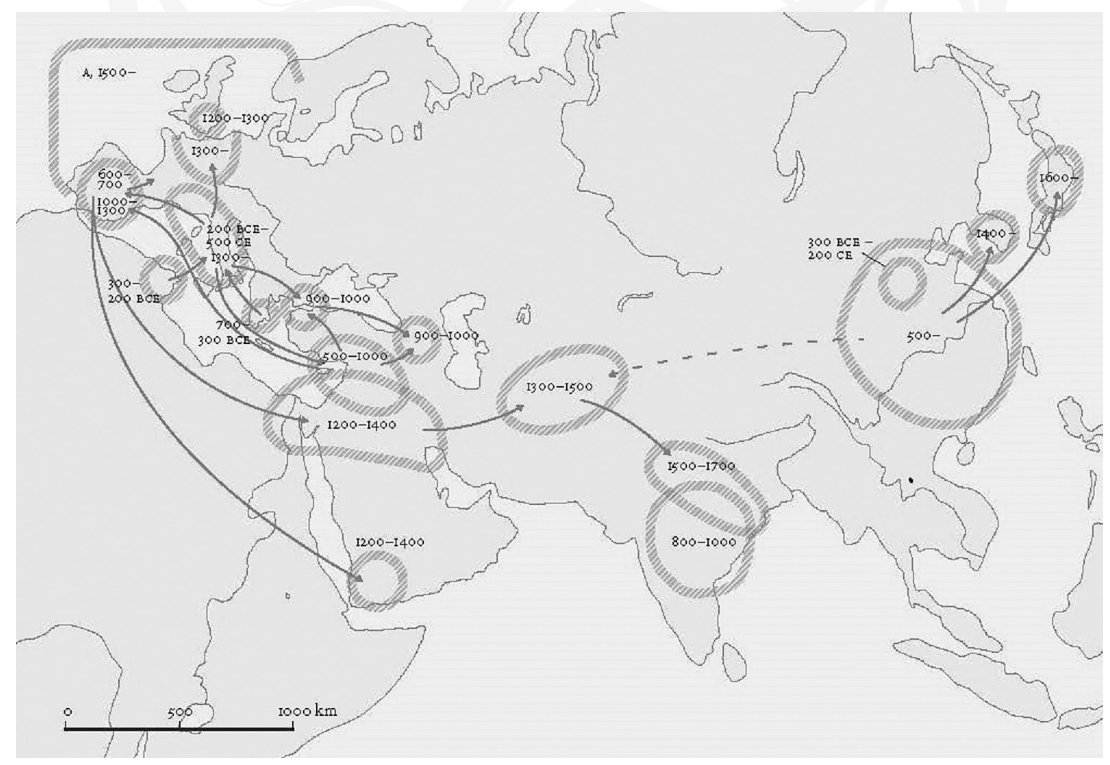

Map 1. Regions Where Agricultural Treatises Were Composed or Compiled, and the Apparent Influences among Regions. Arrows show influence via circulation and translation; circles mark the regions where treatises were produced. One major conclusion to be drawn from this picture is that, although the locus of agricultural treatise production shifts within western and central Eurasia, this region as a whole is comparable to imperial China as a sphere in which there was a continuous exchange of written knowledge. The bracket around Europe after 1500 marks the expansion of publication there after the advent of print.

36 See Appendix for details of the region in which each treatise was composed. 
This data reveals that one to three treatises per century have been preserved from the classical period, covering more than half a millennium. Then, after a phase of stagnation, a new increase is evident, with seven to thirteen treatises preserved per century from 1000 to 1500 . The Mediterranean dominates production in the earliest centuries, but it must be borne in mind that quite a few treatises compiled in China during this same era are known to have been lost. Nothing points to any significant exchange of knowledge, at least via texts, between these two main regions at this early date. This means that the genre of the agricultural treatise was invented independently in different regions. In China, the genre was confined within the empire, but with later offshoots in Korea and later still in Japan. In western and central Eurasia, the geographical trajectory of treatises changed, but there was still one continuous flow of influences. India was a third birthplace for this genre, but probably not until the ninth century CE. From around the tenth century, China and the Islamicate world are dominant producers. Only in the thirteenth century does Christian Europe gradually come into focus, laying the foundations for further expansion in the early modern period.

I have been able to estimate the length of nearly half of these texts, based on word (or character) counts. Of this substantial subset, a quarter are quite brief, between two and ten thousand words (bearing in mind that even shorter texts have not been included in the table). One quarter contain between ten and fifty thousand words, another between fifty and hundred thousand. The remaining quarter are very long treatises, more than a hundred thousand words each, produced in all of the major cultural spheres.

\section{The Greco-Roman and Byzantine Tradition}

Scholarly examination of Greco-Roman treatises has been extensive ${ }^{37}$ and nearly all have been translated into English. All are preserved in medieval manuscript copies, made in both the eastern Roman Empire (Byzantium) and Latin Christendom (see below). Two extant works on agriculture survive from classical Greece. One is Hesiod's Erga kai Hēmerai (Works and Days) from the late eighth century BCE, with about 5,000 words (in verse) devoted to agriculture. The other is the CEconomicus (Household Management) by Xenophon, which dates from the first half of the fourth century BCE and comprises 18,000 words, of which two thirds pertain to agriculture (ca. 12,000 words). A long, but now lost, work is known to have been authored by Mago of Carthage (North Africa) in the third century BCE, translated

37 White, Roman Farming; Butzer, "Classical Tradition"; Christmann, "Agrarschriftsteller"; Diederich, Römische Agrarhandbücher. 
into Latin in 140 BCE. It consisted of twenty-eight books (papyrus scrolls) and was therefore equal in size to Columella's treatise of the first century CE.

From the Roman Empire, we have a series of Latin works produced from the second century BCE to the first century CE, all well known. The two earliest were produced by practitioners and based on their own experience, but also quoting predecessors. Marcus Porcius Cato the Elder composed De agri cultura (On Agriculture) between 170 and 150 BCE, a work of some 26,000 words; and Marcus Terentius Varro wrote his three-volume Rerum rusticarum (Of Rural Matters) in 37-30 BCE, a work of 62,000 words. Virgil's quite influential poem on farming, the Georgica, was authored between 32 and 29 BCE and comprise 23,000 words on agriculture. These were the precursors to Columella's De re rustica (On Rural Matters), a comprehensive work comprising 210,000 words, which he completed in 60-65 CE. All of these books were written in Italy, although Columella grew up in Roman Hispania and certainly drew on that experience. Finally, there is Pliny the Elder's Historia naturalis (Natural History), composed before $79 \mathrm{CE}$, an encyclopedia with five extensive sections on agriculture, amounting to 128,000 words. ${ }^{38}$

A successor of these earlier Roman authors was Palladius, whose goal was to simplify earlier texts but also to codify his own experience as a landholder and farmer in Italy and other parts of the empire. He wrote his Opus agricultura, comprising some 80,000 words (ca. 55,000 in Latin), around 440-445 CE in southern Gaul. ${ }^{39}$ Another influential source of agricultural knowledge was Bishop Isidore of Seville's encyclopedia, the Etymologiae (The Etymologies, 620-636). ${ }^{40}$ Isidore devotes some 10,000 words to agriculture, across five sections of the book. The earliest preserved manuscript is very close to its time of composition, produced in the mid-seventh century, and the book remained immensely popular throughout the Middle Ages. The first printed edition was issued in Germany 1472 and there were ten further printed editions before $1500 .{ }^{41}$

In the regions of the eastern Roman Empire, several works from the second half of the first millennium are attested but now lost. ${ }^{42}$ Those works that have survived are often preserved in later manuscripts, including translations. A book by Vindonius Anatolius, written in Greek in fourth-century Beirut, was translated into classical Syriac (Aramaic) in the sixth or seventh century and into Arabic and Armenian in the tenth or eleventh: it has thus been preserved in these versions.

38 Pliny, Natural History, bks. VIII, XIV, XV, XVIII, and XIX.

39 Bartoldus, Palladius Rutilius, 7-34.

40 Butzer, “Classical Tradition,” 554; Guzman, “Encyclopedias,” 703.

4 I Barney at al., "Introduction."

42 Schreiner, "Landwirtschaftliche Literatur." 
The work of Cassianus Bassus, composed in Greek around 600, is preserved in the later Geoponika (see below) and was translated into Arabic, Persian, and Syriac during the ninth century, and into Armenian around $1200 .{ }^{43}$ A third work from this neighbourhood is the Nabatean Agriculture, which scholars now agree was compiled in or just before the sixth century. ${ }^{44}$ It relates to local customs in Syria and was, to a large extent, preserved in an Arabic translation made by Ibn Wahshiyya the Nabataean in 904, which can be regarded as a separate work (see also below).

The culmination of this Greco-Roman/Byzantine tradition is the aforementioned tenth-century Geoponika, a compilation produced in the imperial scriptorium, ${ }^{45}$ comprising 90,000 words in the English translation. A version was translated into Arabic shortly afterwards, and parts were translated into Latin in the twelfth century. In the early sixteenth century, the full Greek text was published in Germany and several translations into European languages appeared at about the same time: Italian, French, German, and of course also Latin. ${ }^{46}$ Angelo Carrara has claimed that this compilation is in fact a separate regional branch of the larger tradition, and can be traced back to the lost work by Mago of Carthage. ${ }^{47}$

The contents of all these treatises reflect a Mediterranean agricultural system which had been well established for millennia before any texts were composed. In the works by Cato, Columella, and Pliny, the cultivation of wine vines and olive trees constitutes one fifth to one third of the whole text, and this is also true of the Nabatean text and the Geoponika. Arable farming is the subject of one to two tenths of the whole, and animal husbandry about as much. Varro's treatise is thus an outlier in this respect, since he devotes half his book to animal husbandry, with a focus on sheep and goats, but also including a long section on poultry.

\section{The Islamic Tradition: Arabic Texts}

A long research tradition surrounds the Arabic treatises on agriculture ${ }^{48}$ and there is now a website dedicated to this literature and its manuscript sources: the

43 Sezgin, Geschichte, 314-18; Butzer, "Islamic Traditions," 554; Hämeen-Anttila, The Last Pagans, 53. Manuscripts of Vindonius and Bassus are discussed by Carrara, "Geoponica."

44 Hämeen-Anttila, The Last Pagans, 3-33; Hämeen-Anttila has also translated large parts into English.

45 Dalby, "Introduction."

46 White, Roman Farming, 32, 45-46; Dalby, "Introduction," 9-10.

47 Carrara, "Geoponica," 105-6; Hämeen-Anttila, The Last Pagans, is open to that possibility.

48 Butzer, "Islamic Traditions"; see also the section on agriculture under "Filāha" in The Encyclopaedia of Islam. 
Filāḥa Texts Project. ${ }^{49}$ As noted above, these treatises have been discussed in the context of scholarly but also ideological debates over progress in the Islamicate world. ${ }^{50}$ My survey is accordingly based on the Filāha Texts Project and the Encyclopaedia of Islam, as well as the work of other reputable scholars. Several of these Arabic treatises survive only in post-medieval copies. A notable exception is the Nabataean Agriculture of Ibn Wahshiyya, of which fifteen manuscript witnesses survive from the tenth to the fifteenth centuries. As suggested above, this Iraqi polymath's additions to the original (lost) Nabatean text is so extensive that his can be regarded as an independent work. ${ }^{51}$ In total, the work is well over a hundred thousand words long. ${ }^{52}$

The Islamic tradition's flourishing in al-Andalus is at first marked by a strong interest in botany: Fuat Segzin has listed twenty-five known botanical works from the ninth and tenth centuries alone. ${ }^{53}$ This interest is further reflected in the fact that agricultural writers from eleventh and twelfth centuries collected plants and created botanical gardens. Karl Butzer has described their scientific observations as "unrivaled in medieval times," and Andrew Watson showed that these gardens preceded their equivalents in the other parts of Europe by centuries. ${ }^{54}$ The focus on plants also underscores the fact that these treatises were part of a shared Islamic cultural heritage: for instance, the eleventh-century botanist Ibn Bașsaāl recorded descriptions of plants he had encountered on the hajj (pilgrimage to Mecca).

A number of the Andalusian Arabic treatises exist in modern Spanish translations, and the word count below is based on those. Around 1000, an unidentified author composed a treatise comprising 10,000 words. ${ }^{55}$ In the mideleventh century, another was authored by Ibn Wāfid, and a third of his text is preserved in a thirteenth-century Castilian translation; the translation into modern Spanish comprises 12,500 words, and the original would have been close to 40,000 words. ${ }^{56}$ Ibn Bașșāl wrote his treatise, of some 56,000 words, in the late eleventh century. At about the same time, Abū'l-Khayr authored a book which

49 The Filāḥa Texts Project, www.filaha.org/.

50 Watson, Agricultural Innovation; Glick, "Agronomy"; Decker, Tilling the Hateful Earth.

5 I Butzer, "Islamic Traditions”; Hämeen-Anttila, The Last Pagans, 33.

52 Hämeen-Anttila, The Last Pagans.

53 Segzin, Geschichte, 330-46.

54 Butzer, "Islamic Traditions," 27; Watson, "Arab and European Agriculture," 64-65.

55 fi Tartīb Awqāt.

56 Butzer, "Islamic Traditions," 22. The Castilian text is Ibn Wāfid, "La traducción castellana;" see also Ibn Wāfid, Kitāb al-adwiya al-mufrada (a translation into modern Spanish). 
has been incompletely preserved, but what is left comprises 46,000 words in a Spanish translation. ${ }^{57}$ (A little more than 4,000 words on the cultivation of olives and flax have been translated into English. ${ }^{58}$ The peak of this tradition came with a work put together by Ibn al-Awwām in the twelfth century, which comprises an astonishing 490,000 words in a modern French translation. Arabic treatises continued to appear in the Iberian Peninsula through the fourteenth century at least, even as the Muslim kingdoms were threatened and eventually eradicated by the "Reconquista." ${ }^{59}$ At the same time, the production of treatises gradually shifted eastward again. In Yemen, al-Malik al-Ashraf, who eventually became a Mamluk sultan (r. 1290-1293), composed a book describing agriculture in the region. An astronomical work by the same author also includes an almanac of agricultural information. A translation into English of the almanac comprise 5,000 words, about half about agriculture. ${ }^{60} \mathrm{~A}$ hundred years later, the Rasulid sultan of Yemen, al-Malik al-Afdal (r. 1363-1377), also wrote a treatise about farming. In the early modern period, the Islamicate world did not experience the same rapid expansion in publication as China and Europe, though many works were produced or copied.

In general, the content of these Arabic treatises is dominated by the cultivation of fruit and vegetables. In Ibn Wahshiyya's translation and reworking of the Nabatean Agriculture, about half of the text concerns these subjects. According to Butzer, Ibn Bașșāl and Ibn al-'Awwām devote two thirds of their texts to fruit and legumes. ${ }^{61}$ It should be noted that Butzer does not mention that arable farming is not included in Ibn Bașșāl, while Ibn al-'Awwām includes a long section on horses. The earliest extant anonymous treatise from al-Andalus is almost totally focused on arboriculture and cultivated plants, and the same is true for the extant parts of the treatise by Abu'l-Khayr. Ibn Luyūn's treatise, from the fourteenth century, devotes two-thirds of its text to vegetables and fruit. In the major treatises, viticulture is also important, though occupying slightly less than one tenth of the text.

The Filāḥa Texts Project includes some treatises which have not yet been edited, but its description of their contents confirms the conclusions above: Arab writers focused on plants and very seldom mentioned livestock or animal husbandry. The

57 Abū'l-Khayr, Kitāb al-Filāḥa.

58 See www.filaha.org/.

59 Ibn Luyūn, Tratado de agricultura.

60 Varisco, Medieval Agriculture, 23-40.

6 I Butzer, "Islamic Traditions," 18-19. 
exceptions are Ibn al-'Awwām's long section on horses and other animals and also a few other works, such as that of the fourteenth-century Syrian author alDimashqī, who devotes about a tenth of his text to livestock, including doves and bees. The thirteenth-century Yemeni almanac of al-Malik al-Ashraf also contains a significant amount of information on camels.

\section{The Islamic Tradition: Persian Texts, and an Unwritten Link to the East?}

In the Persian lands of the Islamicate world, short entries on agriculture are included in encyclopedias from the tenth to the thirteenth centuries. ${ }^{62}$ At least two extant major works are also known. ${ }^{63}$ The oldest of these was authored ca. 1310-1311 by the renowned and erudite vizier Rashīd al-Dīn, a Jewish convert to Islam. ${ }^{64}$ The second, datable to 1515, was written by Qāsim Yūsuf and comprises 75,000 words; he also wrote a book on irrigation, half as long. ${ }^{65}$ They can be regarded as one work, thus forming about 115,000 words together. As Maria Eva Subtelny has pointed out, both of these lengthy works date from two different periods of agricultural crisis, when nomadic conquerors destroyed crops and fields were neglected. Yūsuf and Rashīd al-Dīn therefore both underscore the importance of sustainable farming and the role of the peasantry. ${ }^{66}$ Rashīd al-Dīn's text is largely devoted to gardening and arable farming (four tenths of the work), with sections on livestock, including poultry and bees (one sixth of the text). Irrigation was also an important topic for him, with one tenth of the text devoted to that subject. ${ }^{67}$

The work of Rashīd al-Dīn, whose career flourished under the Mongol Ilkhanate, is also valuable for displaying some knowledge of Chinese agriculture. Thomas Allsen has shown that the vizier had personal contacts with Bolad Aqa, a Chinese-Mongolian administrator who served as supervisor of the department of agriculture at the Chinese court around 1300 and who then went to central Asia as

62 Vesel, "Les Traités d'agriculture," 99.

63 Vesel, "Les Traités d'agriculture," 100; Lambton, "The Āthār wa ahyō̄'," 129; Subtelny, "A Medieval Persian Agricultural Manual," 168.

64 Subtelny, "A Medieval Persian Agricultural Manual"; Lambton, "The Āthār wa ahyā"; Allsen, Culture and Conquest; Ruymbeke, Science and Poetry.

65 Subtelny, "A Medieval Persian Agricultural Manual"; Subtelny, "Mīrak-i-Sayyid Ghiyās"; Subtelny, "Agriculture and the Timurid Chahārbāgh." Professor Bo Utas has kindly counted the number of words in Persian at my request, and he also helped me with scholarly literature on Persian treatises. See Utas, “'Genres' in Persian Literature.”

66 Subtelny, "A Medieval Persian Agricultural Manual," 195-206.

67 Lambton, "The Āthār wa ahyō'," 129-31. My estimation is based on the number of chapter headings. 
a Chinese envoy. The knowledge of Chinese agriculture in Rashīd al-Dīn's treatise from the early fourteenth century could well be the result of this acquaintance. ${ }^{68}$

Another indication of the intellectual flows between central Asia and China is a closely contemporary Chinese treatise written by the Uighur Lu Ming-Shan, who worked in the Chinese administration, though his treatise does not seem to convey any trace of his background in central Asia. ${ }^{69}$

While there were certainly many such contacts between groups and individuals during the century of Mongol domination in Eurasia, and many oral and practical exchanges of information, we are still dealing with separate textual traditions. ${ }^{70}$ The period of Mongol rule in China itself, the Yuan dynasty, also saw intensive exchanges of agrarian knowledge and technology there and throughout the Mongol khanates, such as the spread of carrot cultivation and the more common cultivation of cotton. ${ }^{71}$ Modern archaeology is producing more and more evidence of how these plants and technologies spread. Contacts and influences were occurring, but there were no direct cross-references between treatises. Why? A possible explanation is that, during these centuries, Chinese agriculturalists were focused on the large-scale dry cultivation and intensive cultivation of wet rice; whereas in central Asia, oases offering more occasional opportunities for irrigation was the more dominant praxis. A broader hypothesis could be that any praxis hardened into a fixed intellectual system-as in China-is less open to influence from other systems. ${ }^{72}$

\section{South Asian Treatises: Hindu and Indian-Islamic Traditions}

Scholarly analysis of Indian agricultural treatises in the Hindu/Sanskrit tradition has been ongoing for quite some time. ${ }^{73}$ So far, only two major agricultural treatises have been dated to the period before 1500 and both have been translated into English. ${ }^{74}$ Why so few? When Irfan Habib initially wrote an entry on this topic in the 1965

68 Allsen, Culture and Conquest, 66-68, 115.

69 Bray, Science and Civilisation, 628. Allsen mentions the book by Lu Ming-Shan, but not that the author came from central Asia; see Culture and Conquest, 118.

70 See for instance, Fernandez-Armesto and Sacks, "Networks."

7I Allsen, Culture and Conquest.

72 Cf. Needham, Science and Civilisation, 239, about medicine.

73 Raghvan, ed., Agriculture in Ancient India, 153-65; Randhawa, A History, 482-89; Ganguly, "Agricultural Technology"; Chaudhuri, "Agriculture."

74 Kāśhyapa, "A Sanskrit Work"; Kāśhyapa, A Treatise on Agriculture; Kāśhyapa, A Sanskrit Work on Agriculture; Parashara, Krsi-Parashara. 
The Encyclopaedia of Islam, he asked this question; however, when his entry was republished in 2011, that paragraph was omitted. ${ }^{75}$ Apparently, his earlier treatment had been interpreted as indicating that literate Hindu elites were uninterested in agriculture. ${ }^{76}$ My conclusion is, rather, that agriculture was considered less Literaturfähig or "text-worthy" than in other ancient and medieval contexts.

In 1994, a group of Indian scholars founded the Asian Agri-History Foundation, in order "to facilitate dissemination of information on agricultural history" and research sustainable practices in South and Southeast Asia. ${ }^{77}$ When I presented a first, preliminary version of this article in 2014 (online, via the Economic History website at Stockholm University), ${ }^{78}$ it was met with some criticism from a leading scholar in this group, partly because my work was taken to suggest that the absence of Indian treatises before 1500 was an indicator of agricultural backwardness. ${ }^{79}$ Here, I must once again stress that the number of extant treatises is not a sign of a more developed or sophisticated agricultural system. It could be that major agricultural treatises still lie dormant in the enormous and largely under-explored archives of South Asia. ${ }^{80}$ In any case, even if the early extant works on agriculture are few, India must still be credited as a third independent birthplace of such works.

Extant manuscripts of the oldest texts identified to date are few, and were copied in the nineteenth and twentieth centuries. The dating of the original treatises is thus insecure and their authorship uncertain. Moreover, they have been attributed to legendary sages of the far-distant past, or to historical figures named after them; but these ancient sages were certainly not the authors. ${ }^{81}$ As Guyla Wojtilla emphasizes, "Sanskrit texts are notoriously difficult to date." ${ }^{22}$ The agricultural treatise attributed to Kāśhyapa, the Kasyapiyakrishisukti, is preserved in a single and late manuscript. The original text has been dated to the second half of the first millennium $\mathrm{CE}^{83}$ and by some more precisely to the eighth or ninth century. ${ }^{84}$ Wojtilla argues instead,

75 Habib, "Filāha, v. India"; Habib, "Agriculture and Irrigation."

76 Mahias, "Présentations."

77 See asianagrihistoryorg/about-us.htm.

78 Myrdal, Agricultural Literature.” Stockholm Papers Economic History no. 15, 2014, https://swopec.hhs.se/suekhi.

79 Nene, "Response to Comments" and "Final Comments; Myrdal, "Agricultural Literature in Eurasia before 1500."

80 Pollock, Language of the Gods, 475, 558.

8I Wojtilla, "Introduction," 9-10, 12.

82 Wojtilla, "Introduction," 11.

83 Randhawa, A History of Agriculture, 484.

84 Wojtilla in Kāśhyapa, "A Sanskrit Work,” 85; Nene, “Commentary,” 132. 
based on its many later interpolations, that the bulk of the text was composed in the later Middle Ages. ${ }^{85}$ In my table, I have erred on the side of antiquity and placed it in the ninth century, though it could have been composed two or three hundred years later. In English it comprises, with the later interpolations, 22,000 words. The second text, the Krishi-Parashara, has also been assigned different dates: between the eleventh and sixteenth centuries, ${ }^{86}$ or between the sixth and eleventh. ${ }^{87}$ Claims to a far more ancient dating have also been made in publications of the Asian AgriHistory Foundation. ${ }^{88}$ I have tentatively placed it around the eleventh century. It comprises nearly 10,000 words, with one fifth devoted to animal husbandry and the remainder to arable farming, and significant attention to water management. Four fifths of the treatise ascribed to Kāśhyapa are also devoted to arable farming and water management, with the remainder divided almost evenly between animal husbandry and gardening and arboriculture. Nothing in either work indicates any contact with Arabic, Persian, or Chinese treatises.

Later extant South Asian agricultural treatises produced in the sixteenth and seventeenth centuries are offshoots of the Islamic tradition's Persian branch. The Asian Agri-History Foundation has published one with an English translation: Nuskha dar Fanni-Falahat (The Art of Agriculture). Its earliest manuscript dates from ca. 1700, but it was authored in the mid-sixteenth century, probably by the courtier Amanullah Husaini. ${ }^{89}$ It is about 11,000 words long in the English translation and includes some discussion of wheat cultivation, but the text is dominated by fruit, vegetables, and arboriculture: very much in line with the Islamic-Arabic tradition. However, this and other Islamicinfluenced treatises composed in South Asia reflect the growing conditions and climate of that particular region, and describe methods and plants suitable to the subcontinent; they therefore constitute a further and site-specific development of this tradition. Other treatises from the seventeenth and eighteenth centuries have also been preserved, and M. Majumdar mentions four and describes the contents of one. ${ }^{90}$ Further references to still more treatises seem to indicate a quite extensive production of such texts in the early modern period. ${ }^{91}$ This

85 Wojtilla, "Introduction," 12-13.

86 Chakravarti, "Agricultural Technology," 223; Ganguly, "Agricultural Technology."

87 Parashara, Krsi-Parashara, xi, xvi; Chaudhuri, "Agriculture," 527.

88 Nene, "Agriculture in General," 81: prior to the fourth century BCE; Nene, "Commentary": between $100 \mathrm{BC}$ and $100 \mathrm{AD}$.

89 Nene, "Foreword," vi.

90 Majunmdar, "Risāka dar Falāhat."

9I Tauer, “Persian Learned Literature," 470; Habib, “Filāḥa, v. India," 910. 
upsurge was connected with the keen interest which Mughal India's Muslim rulers took in the economy of the country, especially its agricultural base. One of the pillars of Eurasian agricultural history is the extremely detailed registration of agricultural products and productivity in northern India at the end of the sixteenth century. ${ }^{92}$

\section{The Chinese Tradition}

Francesca Bray's seminal study of agricultural technology in premodern China (1984) includes a list of agricultural treatises, many of which she discusses in detail. ${ }^{93}$ In 1993, Gang Deng published a study based on an analysis of these treatises. The list I offer in my Appendix draws on both works, among others, and the names of authors and their titles are spelled according to their scholarly conventions. ${ }^{94}$

To date, only a few of these treatises have been translated into English or other European languages. However, there is a full translation of a richly illustrated encyclopedia from the end of the Ming dynasty, with a large section on agriculture, comprising about 11,000 words. ${ }^{95}$ First published in 1637, it was reprinted in two further editions by 1644. (I quoted a passage on draft animals at the outset of this article.) Surviving manuscripts and printed editions of earlier treatises are generally dated much later than the original works. For example, a treatise from the sixth century CE is preserved in two eleventh-century manuscripts now in Japan and another in China, dating from the twelfth. ${ }^{96}$ Other major treatises from the medieval period are preserved in printed editions from the sixteenth century and onward. ${ }^{97}$ Complementing these extant texts, a longstanding bibliographical tradition bears witness to once-existing treatises. Deng's estimate of the total numbers, of which only about a third survive, is as follows: before the Han dynasty, 7; Han (202 BCE-220 CE), 14; diverse polities (221-580), 8; Sui and Tang (581-906), 52; Song and Yuan (960-1368), 133; Ming (1368-1644), 127; Qing (1644-1919), 199. ${ }^{98}$

92 Habib, The Agrarian System; Habib, An Atlas.

93 Bray, Science and Civilisation, 48-73, 621-33. Bray has returned to the agricultural treatises in a series of articles: see Bray, "Thinking with Diagrams," for further references.

94 Deng, Development versus Stagnation. See also Fan "Some Outstanding Works"; Wilkinson, Chinese History.

95 Sung, Chinese Technology; Bray, Science and Civilisation, 76; Deng, Development versus Stagnation, 45, on the importance of this work.

96 Shih A Preliminary Survey, 1.

97 Bray, Science and Civilisation, 49, 56, 60.

98 Deng, Development versus Stagnation, 3; Bray, Science and Civilisation, 47; Wilkinson, Chinese History, 436, with slightly higher numbers. 
Fan Chuyu has identified Lü Shi Chun Qui (Master Lü's Spring and Autumn Annals), dated to 239 BCE, as the earliest of the extant treatises. ${ }^{99}$ This work is a compendium on natural philosophy which contains four essays on agriculture, and is included in my table. ${ }^{100} \mathrm{~A}$ treatise by Fan Sheng-Chih, composed in the first century $\mathrm{BCE}$, is now lost, but quotations in later works have enabled a reconstruction of a portion: once comparable in size to Columella's work, these remains comprise less than six thousand words in an English translation. ${ }^{101}$ Another work from the Han period, composed by Chui Shi in the middle of the second century CE, is also extant in fragments, which have been translated into English. ${ }^{102}$ What is left comprises 3,500 words, slightly more than half of which concerns farming. Because of its original length, it is also included in my table.

The earliest extant work of significant length is that of Jia Sixie (also spelled Chia Ssu-Hsieh), completed between 533 and 544 CE and consisting of some 100,000 characters. ${ }^{103}$ Shih Sheng-Han has provided a detailed description of the contents, with a discussion and partial translation into English of the "original material": namely what Jia Sixtie did not quote from other authors. ${ }^{104}$ Half of the work is devoted to farming, and the rest mainly concerns household management, including culinary recipes. ${ }^{105}$ (In the Appendix I have noted the length of the entire work, since I have not been able to read the full text or gain a thorough understanding its contents.) A book on ploughs, Lei Ssu Ching (Leisi Jing), written ca. 880 by Lu Kuei-Meng (Lu Guimeng) is the first detailed description of tools, which became an important feature of later Chinese treatises. ${ }^{106}$ (It has already been mentioned as an example of those treatises excluded from the table due to its brevity: 693 characters.) While many of the

99 Fan, "Some Outstanding Works," 294. Deng, Development versus Stagnation, 49, refers to an even earlier treatise, which must be regarded as natural history as it is focused on soils.

100 Bray, Science and Civilisation, 48, 626-27.

I0I For a translation, see Shih, "Fan Shêng-Chih Shu"; Bray, Science and Civilisation, 51, for estimation of original size.

102 Translation in Hsu, Han Agriculture, 215-18; about the book, see Bray, Science and Civilisation, 630 and Wilkinson, Chinese History, 437.

103 Bray, "Thinking with Diagrams," 11.

104 Shih, A Preliminary Survey, 31-99.

105 The estimation is based on the proportions of chapters/entries devoted to different subjects: Bray, Science and Civilisation, 57, mentions ninety-two chapters; Deng, Development versus Stagnation, 63, ninety-four entries. Shih, A Preliminary Survey, 3-5, enumerates ninety-two chapters.

106 Deng, Development versus Stagnation, 75-76; date of composition in Bray, Science and Civilisation, 646. 
other surviving treatises largely consist of quotations from earlier works, some are highly original: for example, the treatise written by Chhen $\mathrm{Fu}$ (Chenfu) in 1149 , consisting of some 12,500 characters. ${ }^{107}$ Chhen $\mathrm{Fu}$ is critical of earlier authors, especially Jia Sixie, who focused on conditions in northern China and on the dry farming of millet and barley (though rice is also mentioned). By contrast, Chhen $\mathrm{Fu}$ describes areas dominated by wet rice cultivation around the Yangtse, ${ }^{108}$ thus reflecting a major southward shift in China's economic centre and the increased importance of rice: a shift that became definitive around $1000 .^{109}$

One of the most popular works, Keng Chih Thu (Tilling and Weaving), was first presented to the emperor in 1145 as a series of images, accompanied by a long poem (comprising some 3,000 words in an English translation) that offers detailed descriptions of these processes. The text and images continued to be widely reproduced in the post-medieval era. ${ }^{110}$ An official treatise promulgated by the board of agriculture in 1273, Nung Shan Chi Yao (Fundamentals of Agriculture and Sericulture), has come down to us only in later editions which comprise 60,000 characters. ${ }^{111}$ Another extensive work of this era was composed by Wang Shen in 1313, and comprises 110,000 characters. ${ }^{112}$ Four fifths is devoted to farming, and the rest to other tasks such as textile production. The longest treatise of all is technically post-medieval, authored by Hsû Kuang-Chhi (Xu Guangqi), who died and left the work unfinished in 1633. Entitled Nung Cheng Chhüan Shu (Complete Treatise on Agriculture), it was completed by a group of scholars and published in 1639 , weighing in at a stunning 700,000 characters. Around one quarter of the total is devoted to famine relief; the rest concerns farming. ${ }^{113}$

Significantly, many of these works were composed during unsettled times of agricultural crisis: a period of political fragmentation in the sixth century, in the midst of Mongol rule, and during a cruel civil war in the seventeenth century. Others were written during periods of economic expansion, especially during the

107 Fan, “Some Outstanding Works," 299-300; Deng, Development versus Stagnation, 78-82.

108 Bray, Science and Civilisation, 48.

109 Bray, Science and Civilisation, 9, 427; Deng, Development versus Stagnation, 30-31.

I 10 Hammers, Pictures of Tilling, lists the manuscripts and variants and includes an edited version from ca. 1275, copied into an eighteenth-century manuscript; here, the poem comprises 1,883 characters, of which 878 concern field agriculture and the rest sericulture. See also Bray, Science and Civilisation, 49.

I I I Bray, Science and Civilisation, 71-72.

I 2 Bray, Science and Civilisation, 59-64; Deng, Development versus Stagnation, 82-85.

I 3 Bray, Science and Civilisation, 64-67; Deng, Development versus Stagnation, 86-90. 
twelfth and thirteenth centuries. This long and continuous flow of documentation for one major Eurasian region thus facilitates a comparison of changing trends cover time, mirroring major agrarian changes over a longue durée, ${ }^{114}$ such as the shift to rice cultivation before the eleventh century. Although the earliest treatises from the centuries before and after the beginning of the Common Era appear to be dominated by arable farming, this focus reflects the interests of later authors who quoted excerpts from these works, and does not necessarily capture their original range of interests. In the preserved text of Fan Sheng-Chih, from the first century BCE, about one fifth is devoted to gardening, animal husbandry, and sericulture, and the rest to arable farming. ${ }^{115}$ In the treatises from the sixth century onward, three to four tenths (about one third) are usually devoted to arable farming, and about as much to gardening and arboriculture. Water management was not treated as significant in the earliest treatises but became a topic of increased interest in treatises from the thirteenth century onward, comprising one tenth to a fifth of these texts. Animal husbandry, which in the two latest treatises (1313 and 16331639 ) is dealt with briefly or not at all, occupies one tenth of the earlier treatises. Attention to sericulture was not prominent in the work of Jia Sixie (ca. 540 CE) or in Chhen Fu's 1149 treatise, but increases to between one tenth and one fifth in lengthy works from the twelfth to the seventeenth century, while occupying more than half of the long poem from 1145. Entire monographs on tea production had already been produced during the second half of the first millennium CE (see Appendix). After around 1600, when new crops from the Americas were being introduced into China, these innovations are reflected in both major treatises and in separate monographs.

Meanwhile, Chinese treatises were themselves being exported: to Korea and Japan during the Tang and Song dynasties (before and around 1000), and later to Southeast Asia. ${ }^{116}$ They also generated local offshoots. The first works written in Korean date to the fifteenth century, when the state developed a simpler writing system in order to promote more widespread literacy; the production of agricultural treatises was connected to this program. The most important was Nongsa jikseol or Straight Talk on Farming, compiled in 1430. Another book that circulated as an

II4 My analysis of the medieval treatises is hampered by the lack of complete translations, but Bray and Deng have calculated the amount of attention devoted to each topic based on the number of chapters in those dated to 535, 1149, 1273, 1313, and 1637: Bray, Science and Civilisation, 57, 61, 66, 71; Deng, Development versus Stagnation, 63, 78-79, 87.

II5 That is, about 15 percent on gardening and arboriculture, 4 percent on animal husbandry, 6 percent on sericulture, and the remainder dealing with soils, arable husbandry, and general topics.

II 6 Deng, Development versus Stagnation, 123, 134. 
appendix to this treatise-in reality, a separate work-was produced at the end of this century. (Both are included in my table.) They also inspired newer works. ${ }^{117}$ Japanese treatises in this tradition are post-medieval, although an agricultural manual included in a book on military campaigns from the late seventeenth century may contain older elements from the sixteenth century. ${ }^{118}$ The first comprehensive Japanese treatise appeared in 1697 , according to the writer's own declaration. ${ }^{119}$ At this time, further treatises had been produced in Korea and in China as well.

Chinese treatises were often richly equipped with images, and illustrated works survive in printed copies from as early as the twelfth century. The first long and fully illustrated work was the lengthy treatise of Wang Chen (1313), ${ }^{120}$ and this was followed by a whole series of others. Obviously, these illustrations are an extremely important resource for the historian, especially since there are very few in treatises from elsewhere in Eurasia. That said, many images of agrarian activity appear in manuscripts and other contexts, for instance in botanical works. ${ }^{121}$ In Byzantium, manuscripts of Hesiod were illustrated with farming scenes, ${ }^{122}$ and several illustrated manuscripts of Columella, Pliny, and Virgil (among others) were produced in later medieval Europe. ${ }^{123}$

\section{Latin Christendom after $800 \mathrm{CE}$}

The medieval tradition of agricultural writing in Latin Europe has long been the subject of research. ${ }^{124}$ Most major treatises have been edited and published in modern translations. The number of extant manuscripts grows from very few around the year 1000 to mass production at the end of the Middle Ages, in keeping with wider documentary trends. In contrast to the other medieval regions we have surveyed, the earliest manuscript copies of medieval European treatises were often produced quite close to the time of their original composition.

In England, short texts on estate management were produced in the ninth and tenth centuries (in Old English with Latin translations) and are preserved

117 Lee, A New History of Korea, 193, 195, 240-41.

II8 Smith, Agrarian Origins, 89; Farris, Japan's Medieval Population, 224-25.

I 19 Smith, Agrarian Origins, 87-93; Bray, Science and Civilisation, 625-27.

120 Bray, “Thinking with Diagrams," 16-20.

I 2 I Mane, Le Travail à la campagne.

122 Schreiner, "Landwirtschaftliche Literatur."

123 Mane, Le Travail à la campagne, 46-50.

124 Frauendorfer, Ideengeschichte; Fussell, Classical Tradition. 
in manuscripts from the twelfth century. ${ }^{125}$ They were precursors to a genre that flourished at the end of the thirteenth century, when a number of closely related treatises on manorial accounting appeared in Latin and Anglo-Norman French: we encountered one of them at the beginning of this article. These texts are so specific to their insular context that medieval England could well be considered an independent birthplace of the agricultural treatise. Indeed, thousands of account rolls from the thirteenth through fifteenth centuries have been preserved, from hundreds of English manors. They form one of the finest source materials for the detailed study of farming praxis in all of premodern Eurasia.

Three agricultural treatises in particular were widespread as practical handbooks for those who managed manorial estates. All were written in French and all are interrelated, though they differ in structure and emphasis. Dorothea Oschinsky has edited the original texts, and has also translated two into modern English; for the third, by Walter of Henley, she reprinted a 1508 English edition. ${ }^{126}$ Two, the anonymous Seneschauchie (Stewardship) and Le dite de hosebondrie (Discourse on Husbandry) attributed to Walter, date from around 1280 and comprise more than seven thousand words each. The third, Ceo est hosebonderie (This Is about Husbandry) from the end of that century, is half as long. Around seventy medieval manuscripts have survived, in total, and more than half are copies of Walter of Henley's treatise. Although none of these works quote older Roman authors, George Fussell once speculated that the English authors had read some classical texts. ${ }^{127}$ This is questionable, however, considering that manorial accounting was taught outside the scholastic milieu, and even at contemporary universities the classical agricultural writers were largely unknown. Rather, it is clear that these treatises reflect local traditions, not the Mediterranean farming techniques of antiquity. One further text has come down to us in a single copy, the so-called Scriptum quodam (Certain Writing) from Gloucester Abbey: the incipit of a set of instructions included in the monastery's cartulary and compiled in the second half of the thirteenth century. It comprises around 2,500 words and, due to its brevity, is not included in my table. ${ }^{128}$

125 Banham and Faith, Anglo-Saxon Farms, 8-9.

126 Oschinsky, Walter of Henley. Oschinsky also edited a further treatise from the first half of the thirteenth century, mainly about manorial administration. For some corrections of these translations, see Harvey, "Agricultural Treatises," 180-82.

127 Fussell, Classical Tradition, 65.

128 Historia et cartularium 1867, xcvii-c, 213-21. For a discussion and dating of the document, see Hilton, A Medieval Society, 86-87. 
Classical texts reached Christian Europe along two paths: via late antique or Carolingian copies of Latin authors or via translations from extant Greek texts by Arabic scholars. In al-Andalus, Ibn Wāfid's Arabic treatise was translated into Castilian in the thirteenth century and later influenced the work of Gabriel Alonso de Herrera, published in 1513 (see below). ${ }^{129}$ From the ninth to the thirteenth century, we also have works by medieval authors, like the Benedictine monk Wandelbert of Prüm (813-ca. 850) and the Dominican theologian Albertus Magnus (ca.1193-1280), both of which contain short sections on agriculture with reference to classical authorities (not included in the table). ${ }^{130}$ The first major agricultural work created in the medieval period on the Continent was that of the Bolognese jurist Pietro de' Crescenzi (also known as Petrus de Crescentiis), composed in the first decade of the fourteenth century. Entitled the Ruralia commoda (Rural Rewards), it comprises some 140,000 words in the Latin original (around 220,000 words in a modern German translation). ${ }^{131}$ This work survives in more than one hundred and thirty manuscripts, the earliest being from 1339. In the fourteenth century, it was translated into Italian, French, and German. In the late fifteenth century, it was again translated into German and saw further translations into Czech, Polish, and Russian. ${ }^{132}$ Crescenzi based much of his work on Palladius and he also quoted other Roman authors, but he had not read Columella directly (though he knew of his works). The famous Muslim philosopher Ibn Sīnā (Avicenna, ca. 980-1037) was also one of his main sources, although Crescenzi does not mention the Arabic agronomists and may not have had any direct knowledge of their works. ${ }^{133}$ This was also the first agricultural treatise to be printed in Europe, published at Augsburg in 1471, with eight reprints following before 1500. ${ }^{134}$

The medieval French translation of Crescenzi's book was commissioned by King Charles V (r. 1364-1380), who also commissioned a treatise specifically dedicated to animal husbandry as a supplement. The author of the latter was Jean de Brie, a former shepherd; presumably, he had some help in composing it. Published in 1379 , this book survives in a printed edition from the early sixteenth century, with a number of later additions. It comprises some 20,000 words in both Old French

129 Colin, "Agriculture (Ar. filāha)," 7.

130 Butzer, “Classical Tradition," 562-78; Frauendorfer, Ideengeschichte, 58-60.

131 Crescentiis, Erfolgreiche Landwirtschaft.

132 Mane, Le Travail à la campagne, 32; Vollman, "Einleitung."

I 33 Comet, "Le Statut intellectuel," 29; Glick, "Agronomy."

134 Fussell, Classical Tradition, 92; Vollman, "Einleitung," 9. 
and modern English translation. ${ }^{135}$ In the fifteenth century, two longer agricultural treatises appeared in Italy, by Corniolo della Cornio and Michelangelo Tanaglia. ${ }^{136}$

The fifteenth century was characterized by a renewed interest in the classical authors, in keeping with wider humanist intellectual trends. There are a hundred known manuscripts of Palladius and forty of Columella's treatise from this time. ${ }^{137}$ Palladius was also translated into English (1442) ${ }^{138}$ and Columella into Swedish (ca. 1520). ${ }^{139}$ Printing further spread the circulation of older texts, as we noted above in our discussion of Isidore and the Geoponika. Pliny the Younger's work was printed in dozens of editions in the late fifteenth century; Columella's four times; and an anthology including the works of Varro, Columella, and Palladius eleven times. ${ }^{140}$ Printing also meant that more books were illustrated with woodcuts and engravings, both classical authors and the work of Crescenzi. ${ }^{141}$ In the sixteenth century, newer treatises also appeared in print. Gabriel Alonso de Herrera's Obra de Agricultra (250,000 words) was first published in 1513, with many later and expanded editions to follow. ${ }^{142}$ After Walter of Henley's treatise, printed for the first time $1508,{ }^{143}$ the Boke of Husbandry by the jurist Anthony Fitzherbert (1470-1538), the first new treatise in English, was published just beyond the chronological scope of this article, in 1523; the 1534 edition is available online and comprises 53,000 words. ${ }^{144}$ It contains no references to previous authors, except in Fitzherbert's moralizing final section, where he mentions some classical authorities (though not the agricultural writers).

With respect to their contents, it is obvious that these European treatises reflect two very different agricultural systems: that of the Mediterranean littoral and that of northwestern Europe. Crescenzi, in the early fourteenth century, and

135 Brie, The Medieval Shepherd.

I 36 Comet, "Le Statut intellectuel," describes Cornio's treatise; Mane, Le Travail à la campagne, 53 , also mentions Tanaglia.

137 Josephson, Die Columella-Handschriften; Hedberg, Contamination and Interpolation.

138 Ficht, "Introduction."

139 Granlund, Peder Månssons Bondakonst: the classical text is adjusted and supplemented to suit northerly conditions.

140 Beutler, “Un Chapitre de la sensibilité," 1297.

14I Mane, Le Travail à la campagne, 46-54.

142 For an abbreviated translation into English of a later edition, see Herrera, Ancient Agriculture; the later editions also exist in modern Spanish reprints.

143 Published, as noted above, by Oschinsky, Walter of Henley.

144 Master Fitzherbert: Internet Archive www.archive.org/details/bookofhusbandry00 fitzuoft. 
Herrera, two hundred years later, describe the former. Their sections on fruit trees, viticulture, and gardening constitute about half of their works, with one quarter devoted to animal husbandry and the remainder mainly to field farming. ${ }^{145}$ They are thus closer to their Roman predecessors than to the medieval Arabic authors in their attention to animal husbandry. For northern Europe, Jean de Brie's French supplement to Crescenzi's work represents an important step toward addressing the vital praxis of sheep farming, which was so central to the entire northwestern European economy. The three treatises from late thirteenth-century England each devote about half of their text to animal husbandry and the rest to arable farming (two fifths to livestock for Walter of Henley, and three fifths for the two others). The short text from Gloucester has the same focus. Two hundred years later, Fitzherbert's Boke of Husbandry is nearly half about arable farming, nearly half about animal husbandry, and less than one tenth dedicated to gardening.

\section{A Test of the Iceberg Method}

One subset of the treatises from medieval Europe can serve as a case study for testing the Iceberg Method introduced at the beginning of this article: works produced in Sweden. I have read virtually all of the existing medieval documentation on agriculture extant in Sweden (charters, law codes, miracle stories, etc.) and a fair portion of the sixteenth-century sources, too. In other words, I know not only the tip of the iceberg, but also almost everything submerged below the surface. The first short texts on farming in Sweden appear in the late fifteenth century. In the first years of the sixteenth, a Swedish translation of Columella was published. Also in the sixteenth century, shorter works of instruction multiplied, while the first long agricultural treatise was authored and disseminated in manuscript during the second half of that century. ${ }^{146}$ In the sixteenth century, manorial accounts (compiled on state-owned manors) were produced to an extent comparable with the situation in later medieval England. With some delay, then, Sweden followed the general European pattern. The first printed books on agriculture did not appear until the end of the seventeenth century, as in other countries on Europe's northern periphery.

The methodological takeaway, then, is that the tip of the Swedish iceberg — that first long treatise from the sixteenth century-represents an increasing textual interest in agriculture: the moment when it became Literaturfähigkeit, worthy of its own literature. Hence, I posit that the Iceberg Method is a more generally applicable way to measure the emergence of other textual genres and therefore

I 45 Butzer, "Islamic Traditions," 19.

146 Myrdal, Medeltidens åkerbruk; Myrdal, Boskapsskötseln. 
to achieve comparable data sets for global history. Rather than relying on a few chosen examples, it helps to reveal deeper processes and times of profound change.

\section{Conclusions}

As for so many other innovations, the first glimpse of a written tradition of agricultural knowledge is quite early: a brief Sumerian text from Mesopotamia, ca. 1800 BCE. Another written tradition then arose in Greece, nearly three thousand years ago. However, continuous traditions of agricultural writing in the major regions of Eurasia did not begin until the third century BCE. The survey presented here demonstrates that agricultural treatises then emerged in two different regions independently and simultaneously: in the eastern Mediterranean and in China. During the Middle Ages, this genre also emerged independently in India. I have also observed that the specific conditions of manorial management and pragmatic literacy in thirteenth-century England could be regarded as a fourth independent invention of this genre.

The continuity of the two great traditions in eastern and western Eurasia is more visible in China, where the production and dissemination of treatises was often fostered by centralized imperial authority. In western regions, we encounter an assiduous process of writing, rewriting, and innovation, though with a shifting geographical trajectory. From Greco-Roman antiquity this genre spread to-and was preserved in-the eastern Roman Empire and in the Islamicate world: early in al-Andalus and then in the Levant (Syria, Yemen), Persia (including modernday Afghanistan), and finally in early modern India, where the Islamicate textual tradition apparently overwhelmed existing Hindu traditions. Meanwhile, a post-classical genre of agricultural writing in Latin Christian Europe developed relatively late. Here, too, the influence of Arabic authors from al-Andalus is evident, alongside the reception of Roman authors. England represents its own unique insular tradition, developing in close connection with management of a manorial economy. In all of the major regions, there was a gradual increase in textual production around $1000 \mathrm{CE}$, again in keeping with broader trends.

The content of all these treatises reveals constant adjustment to regional agricultural systems and environmental factors. However, it was also shaped by longstanding preferences that developed in the separate branches of the great traditions, the focus on botany in Islamic treatises being a significant example. Changes in farming practices also entailed an ongoing reformulation of their content, as when treatises from Mediterranean had to be adapted to the conditions of northern Europe, or as wet rice cultivation in southern China displaced millet farming in the northern parts of the empire. 
An abiding enigma is the lack of apparent interconnection between these two great Eurasian traditions, even though we know that there were many opportunities and occasions for contact. Intellectual influences, technologies, and plant and animal species moved with trade and conquest throughout this vast area-but not treatises as such. This is partly explained by the fact that two different ways of documenting agricultural praxis had already developed over a long period of time. In other words, both traditions had reached a high degree of intellectual crystallization, which may have stalled the written transmission of that information.

This leads to my grand hypothesis. The agricultural treatises that have come down to us reflect an increasingly systematic approach to agriculture in much of Eurasia from the middle of the first millennium BCE onward. From around the sixth century BCE to the second century $\mathrm{CE}$, more complex and integrated agricultural systems were forming: iron not only replaced bronze but also paved the way for the invention of a whole new farming tool kit. Meanwhile, the long and intricate chains of trade had been developing since the beginning of the Bronze Age, in part because the copper and tin necessary for the production of bronze were only to be found sparsely and in widely separated regions. Even though iron is more readily available in many places, its advent in the long run actually intensified interregional trade, because of increased surplus production. At the same time, the geographical division of labour became not only an asset but a necessity for all agricultural enterprises. After the sixth century BCE, the market for iron expanded on both the regional and local level, while long-distance trading networks continued to flourish, now more focused on luxury products. Because iron was needed by many more users and had many more functions, metallurgy ceased to be something rare and became a common technology. Not only the forging of metals, but a range of other crafts developed and innovated dramatically and rapidly, such as carpentry: again with a new iron tool kit. New and more efficient agricultural tools and methods became widespread. All of these changes led to more complex modes of agricultural production and more specialization.

At the same time, the scale of political organization grew alongside the development of allied military technologies (infantry with a mass of soldiers armed with iron weapons), with expanding administrations demanding heavier taxes, which also effected agricultural change. At the level of the farm, these and other factors meant there was a need for a different kind of ingenuity and longer-term planning. Farming units became more directly integrated into economic systems that spread over enormous regions. The global agricultural systems as we know them emerged and developed in a path-dependence fashion: intensive wet rice cultivation in East Asia, diversified Mediterranean agriculture designed to withstand the summer 
drought, and the northern European reliance on animal husbandry integrated with arable farming. ${ }^{147}$

All of these changes, which began in the middle of the first millennium BCE, could have made it necessary to conceptualize agriculture in a more systematic way. According to my hypothesis, this is what made agriculture Literaturfähig, something worth writing about. Hence the emergence of the two great traditions that prevailed until the early modern period, with some important changes-again on a pan-Eurasian plane-around $1000 \mathrm{CE}$. To some extent, this grand hypothesis is related to scholarly discussions about "Axial Ages"148 marked by an increasing historical reflexivity and awareness of change. However, those who advocate for such theories often lack hard data to sustain their arguments. ${ }^{149}$ Here, I present such a data set, from a totally different perspective than religion and philosophy, but contemporaneous to that of a presumed Axial Age.

The main goal of this article is not, however, to support these overarching and tantalizing theories. Rather, it is to offer a useful data set (see the Appendix) and synthesis of our state-of-the art knowledge regarding the composition and circulation of agricultural treatises in Eurasia over the span of two millennia. In so doing, it has also shown how and when agricultural knowledge became something that required documentation, thus making a contribution to the ongoing study of pragmatic literacy.

147 Grigg's Agricultural Systems is still the best work on the history of agricultural systems; on parallel processes in Eurasia see Lieberman, Strange Parallels.

148 See, for instance, Eisentadt, Origins and Diversity.

149 Myrdal, "On Source Criticism," 70-79. For a statistical test of some of the features, see Mullins et al., "A Systematic Assessment." 


\section{Bibliography}

Abū'l-Khayr. Kitāa al-Filāḥa. Edited and translated by J. M. Carabaza Bravo. Madrid: Agencia Española de Cooperación Internacional, Instituto de Cooperación con el Mundo Árabe, 1991.

Allsen, Thomas. Culture and Conquest in Mongol Eurasia. Cambridge: Cambridge University Press, 2001.

al-Malik al-Ashraf: see Varisco.

Asian Agri-History Foundation. www.asianagrihistory.org

Banham, Debby, and Rosamond Faith. Anglo-Saxon Farms and Farming. Oxford: Oxford University Press, 2014.

Barnard, John, and Maureen Bell. "Statistical Tables." In The Cambridge History of the Book in Britain, vol. 4: 1557-1695, edited by John Barnard and D. F. McKenzie, 779-93. Cambridge: Cambridge University Press, 2014.

Barney, Stephen A., W. J. Lewis, J. A. Beach, and Oliver Berghof. "Introduction." In The Etymologies of Isidore of Seville, translated by S. A Barney, W. J. Lewis, J. A. Beach, and Oliver Berghof, 3-31. Cambridge: Cambridge University Press, 2006.

Bartoldus, Marcus Johannes. Palladius Rutilius Taurus Aemilianus Welt und Wert spätrömischer Landwirtschaft. Augsburg: TZ-Verlag, 2012.

Baten, Joerg, and Jan Luiten van Zanden. "Book Production and the Onset of Modern Economic Growth." Journal of Economic Growth 13 (2008): 217-35.

Beutler, Corinne. "Un Chapitre de la sensibilité collective: la littérature agricole en Europe continentale au XVIe siècle." Annales: économies, sociétés, civilisations 28 (1973): 1280-301.

Bray, Francesca. Science and Civilisation in China, vol. 6: Biology and Biological Technology, Part II: Agriculture. Cambridge: Cambridge University Press, 1984.

—. "Thinking with Diagrams: The Chaîne Opératoire and the Transmission of Technical Knowledge in Chinese Agricultural Texts." East Asian Science, Technology and Society: An International Journal 14 (2020): 1-26.

Brie, Jean de. The Medieval Shepherd: Jean de Brie's "Le bon berger" (1379). Edited and translated by Carleton W. Carrol and Lois Hawley Wilson. Tempe: Arizona Center for Medieval and Renaissance Studies, 2012.

Britnell, Richard. "Pragmatic Literacy in Latin Christendom." In Pragmatic Literacy, East and West, 1200-1300, edited by Richard Hugh Britnell, 3-24. Woodbridge: Boydell \& Brewer, 1997.

Butzer, Karl W. "The Classical Tradition of Agronomic Science: Perspectives on Carolingian Agriculture and Agronomy." In Science in Western and Eastern 
Civilization in Carolingian Times, edited by Dietrich Lohrmann and Paul L. Butzer, 539-96. Basel: Birkhäuser, 1993.

—. "The Islamic Traditions of Agroecology: Crosscultural Experiences, Ideas and Innovations." Ecumene: A Journal of Environment, Culture, Meaning 1 (1994): 7-50.

Carrara, Angelo Alves. “Geoponica and Nabatean Agriculture: A New Approach into Their Sources and Authorship." Arabic Science and Philosophy 16 (2006): 103-32.

Cato, Marcus Porcius, and Marcus Terentius Varro. On Agriculture. Translated by William Davis Hopper and Harrison Boyd Ash. Cambridge: Harvard University Press, 1935.

Chakravarti, Ranabir. "Agricultural Technology in Early Medieval India (c. A.D. 500-1300)." The Medieval History Journal 11 (2008): 229-58.

Chaudhuri, Rita. "Agriculture as Known from Khanā's Vacanas." In History of Agriculture in India, up to c. 1200 A.D., edited by Lallanji Gopal and V. C. Srivastava, 527-49. New Delhi: Centre for Studies in Civilizations (CSC), 2008. Christmann, Eckhard. "Agrarschriftsteller." In Der neue Pauly. Enzyklopädie der Antike, vol. 1, 282-86. Stuttgart: Metzler, 1996.

Chui Shi: see Hsu

Civil, Miguel, The Farmer's Instructions: A Sumerian Agricultural Manual, Aula Orientalis 5: Supplementa. Sabadel: Editorial Ausa, 1994.

Colin, G. S. "Agriculture (Ar. filāha): Muslim West." In Food Culture and Health in Pre-Modern Islamic Societies, edited by David Waines, 4-7. Leiden: Brill, 2011. Columella, Lucius Junius Moderatus. On Agriculture, Vols I-III. Edited and translated by E. S. Forster and Edward H. Heffner. Cambridge: Harvard University Press, 1941-55.

Comet, Georges. "Le Statut intellectuel des savoirs agricoles au Moyen Âge." In Traditions agronomiques européennes: élaboration et transmission depuis l'Antiquité, edited by Marie-Claire Amouretti and François Sigaut, 27-41. Paris: Éditions du CHTS, 1998.

Crescentiis, Petrus de. Erfolgreiche Landwirtschaft: Ein mittelalterliches Lehrbuch, Vols. 1-2, translated by Benedikt Konrad Vollman. Stuttgart: Hiersemann, 2007-8. Dalby, Andrew. "Introduction." In Geoponika: Farm Work. A Modern Translation of the Roman and Byzantine Farming Handbook, translated by Andrew Dalby, 9-18. Totnes: Prospect, 2011.

Decker, Michael. Tilling the Hateful Earth: Agricultural Production and Trade in the Late Antique East. Oxford: Oxford University Press, 2009.

Deng, Gang. Development versus Stagnation: Technological Continuity and Agricultural Progress in Pre-modern China. Westport: Greenwood, 1993. 
Diederich. Silke. Römische Agrarhandbücher zwischen Fachwissenschaft, Literatur und Ideologie. Berlin: de Gruyter, 2007.

Eisenstadt, Shmuel Noah, ed. The Origins and Diversity of Axial Age Civilizations. Albany: State University of New York Press, 1986.

The Encyclopedia of Islam, vols. 1-12, 2nd ed. Leiden: Brill, 1954-2004.

Fan Chuyu. "Some Outstanding Works on Agriculture." In Ancient China's Technology and Science, 292-304. Beijing: Foreign Languages Press, 1983.

Fan Shêng-Shi: see Shih

Farris, William Wayne. Japan's Medieval Population: Famine, Fertility, and Warfare in a Transformative Age. Honolulu: University of Hawai'i Press, 2006.

Fernández-Armesto, Felipe, and Benjamin Sacks. "Networks, Interactions, and Connective History." In A Companion to World History, edited by Douglas Taylor Northrop, 303-20. Chichester: Wiley-Blackwell, 2012.

Ficht, John G. "Introduction.” In Palladius, “Opus Agriculturae”: The Work of Farming, translated by John G. Ficht, 11-28. Blackawton: Prospect, 2013.

Filāḥa Texts Project: The Arabic Books of Husbandry. www.filaha.org/.

Fitzherbert, Anthony. The Book of Husbandry. London: English Dialect Society, 1882.

Frauendorfer, Sigmund von. Ideengeschichte der Agrarwirtschaft und Agrarpolitik im deutschen Sprachgebiet, vol 1: Von den Anfängen bis zum ersten Weltkrieg. Bonn: Bayerischer Landwirtschaftsverlag, 1957.

Fussell, George Edwin. The Classical Tradition in West European Farming. Newton Abbot: David \& Charles, 1972.

Ganguly, D. K. "Agricultural Technology as Known from the Krsi-Parāsara." In History of Agriculture in India, up to c. 1200 A.D, edited by Lallanji Gopal and V. C. Srivastava, 510-26. New Delhi: Centre for studies in civilizations (CSC), 2008.

Geoponika: Farm Work. A Modern Translation of the Roman and Byzantine Farming Handbook. Translated by Andrew Dalby. Totnes: Prospect, 2011.

Glick, Thomas. "Agronomy." In Medieval Science, Technology, and Medicine: An Encyclopedia, edited by Thomas Glick, Steven J. Livesey, and Faith Wallis, 1013. New York: Routledge, 2005.

Goody, Jack. The Logic of Writing and the Organization of Society. Cambridge: Cambridge University Press, 1986.

Granlund, John. Peder Månssons Bondakonst. Uppsala: Svenska fornskriftsällskapet, 1983.

Grigg, D. B. The Agricultural Systems of the World: An Evolutionary Approach. Cambridge: Cambridge University Press, 1974.

Guzman, Gregory G. "Encyclopedias." In Medieval Latin: An Introduction and Bibliographical Guide, edited by Frank Anthony Carl Mantello and Arthur George Rigg, 702-7. Washington, DC: Catholic University of America Press, 1996. 
Habib, Irfan. The Agrarian System of Mughal India 1556-1707. 2nd ed. Oxford: Oxford University Press, 1999.

—. "Agriculture and Irrigation: W. India." In Food-Culture and Health in PreModern Islamic Societies, edited by David Waines, 14-16. Leiden: Brill, 2011.

—. An Atlas of the Mughal Empire: Political and Economic Maps. New Delhi: Oxford University Press, 1982.

_ . "Filāḥa, v. India." In The Encyclopaedia of Islam, Vol. 2, edited by P. Bearman, T. Bianquis, C. E. Bosworth, E. van Donzel, and W. P. Heinrichs, 909-10. 2nd ed. Leiden: Brill, 1965.

Hämeen-Anttila, Jaakko. The Last Pagans of Iraq: Ibn Wahshiyya and His Nabatean Agriculture. Leiden: Brill, 2006.

Hammers, Roslyn Lee. Pictures of Tilling and Weaving: Art, Labor, and Technology in Song and Yuan China. Hong Kong: Hong Kong University Press, 2011.

Harvey, D. P. A. "Agricultural Treatises and Manorial Accounting in Medieval England." Agricultural History Review 20 (1972): 170-82.

Hedberg, Sten. Contamination and Interpolation: A Study of the 15th Century Columella Manuscripts. Uppsala: Uppsala University, 1968.

Henley, Walter, see Oschinsky

Herrera, Gabriel Alonso de. Ancient Agriculture: Roots and Application of Sustainable Farming. Edited by Juan Estevan Arello, translated by Rosa LópezGastón. Layton: Ancient City Press, 2006.

— Obra de Agricultura. Edited by Jose Urbano Martinewz Carreras. Madrid: Atlas, 1970.

Hesiod. Theogony, Works and Days, Testimonia. Edited and translated by Glenn W. Most. Cambridge: Harvard University Press, 2006.

Hilton, R. H. A Medieval Society: The West Midlands at the End of the Thirteenth Century. London: Weidenfeld and Nicolson, 1966.

Historia et cartularium monasterii Sancti Petri Gloucestiae, Vol. 3. Edited by William Henry Hart. Cambridge: Cambridge University Press, 1867.

Hsu Cho-yun. Han Agriculture: The Formation of Early Chinese Agrarian Economy, 206 B.C.-A.D. 220. Seattle: University of Washington Press, 1980.

Ibn al-Awwām. Le Livre de l'agriculture. Traduction revue et corrigée. Translated by J.-J. Clément-Mullet. Arles: Actes Sud, 2000.

Ibn Bașșāl. Libro de agricultura. Translated by Millás Vallicrosa. Seville: Sevilla Equipo, 1995.

Ibn Luyūn. Tratado de agricultura. Edited and translated by Joaquina Eguaras Ibáñez. Granada: Patronato de la Alhambra y Generalife, 1988.

Ibn Wāfid. Kitāb al-adwiya al-mufrada (Libro de los medicamentos simples). Translated by Luisa Fernanda Aguirre de Carcer. Madrid: Consejo 
Superior de Investigaciones Científicas, Agencia España de Cooperacción Internacional, 1995.

Ibn Wāfid. "La traducción castellana del 'Tradado de agricultura' de Ibn Wâfid."

Translated by José María Millás Vallicrosa. Al-Andalus 8 (1943): 281-332.

Ibn Waḥshiyya: see Häämen-Antilla

Internet Archive. www.archive.org

Isidore of Seville. The Etymologies of Isidore of Seville. Translated by Stephen

A Barney, W. J. Lewis, J. A. Beach, and Oliver Berghof. Cambridge: Cambridge University Press, 2006.

Josephson, Åke. Die Columella-Handschriften. Uppsala: Uppsala University, 1955.

Kāśhyapa. Kashyapiyakrishisukti: A Sanskrit Work on Agriculture. Edited and translated by Gyula Wojtilla. Wiesbaden: Harrassowitz, 2010.

. "Kāśyapīyakrsisūkti: A Sanskrit Work on Agriculture." Edited and translated

by Gyula Wojtilla. Acta Orientalia Academiae Scientiarum Hungaricae 29 (1985): 85-136.

- Kashyapiyakrishisukti: A Treatise on Agriculture by Kashyapa. Translated by

S. M. Ayachit. Secunderabad: Asian Agri-History Foundation, 2002.

Kitāb fĩ Tartīb Awqāt al-Ghirāsa wa 'l-Maghrūsāt: Un Tratado Agrícola Andalusí

Anónimo. Edited and translated by A. C. López y López. Granada: Consejo Superior de Investigaciones Científicas, 1990.

Lambton, Ann K. S. "The Āthār wa ahyyā' of Rashīd Al-Dīn Faḍl Allāh Hamadānī and

His Contribution as an Agronomist, Arboriculturist and Horticulturalist." In

The Mongol Empire \& Its Legacy, edited by Reuven Amitai-Preiss and David

0. Morgan, 126-54. Leiden: Brill, 2000.

Lee Ki-Bai. A New History of Korea. Seoul: Ilchokak, 1984.

Li Xiaoyun, Qi Gubo, Tang Lixia, Zhao Lixia, Jin Leshan, Guo Zhandeng, and Wu

Jin. Agricultural Development in China and Africa: A Comparative Analysis.

New York: Routledge, 2012.

Lieberman, Victor B. Strange Parallels: Southeast Asia in Global Context, c. 800-1830,

vol. 1: Integration on the Mainland. Cambridge: Cambridge University Press, 2003.

Mahias, Marie-Claude. "Présentations, réflexions pour une ethnologie des

techniques en Inde." Techniques et culture 14 (1989): 1-21.

Majumdar, M. "Risāka dar Falāhat: Persian Manuscript on Agriculture and Horticulture." Indian Journal of History of Science 19 (1984): 341-60.

Mane, Perrine. Le Travail à la campagne au Moyen Âge: étude iconographique. Paris: Picard, 2006.

McKitterick, David. "Bibliography, Population, and Statistics: A View from the West." In The Book Worlds of East Asia and Europe 1450-1850, edited by Joseph 
P. McDermott and Peter Burke, 65-104. Hong Kong: Hong Kong University Press 2015.

Meier, Christel. "Fourteen Years of Research at Münster into Pragmatic Literacy in the Middle Ages." In Transforming the Medieval World: Uses of Pragmatic Literacy in the Middle Ages, edited by Franz-Josef Arlinghaus, Marcus Ostermann, Oliver Plessow, and Gudrun Tscherpel, 23-39. Turnhout: Brepols, 2006.

Mokyr, Joel. The Enlightened Economy: An Economic History of Britain, 1700-1850. New Haven: Yale University Press, 2009.

Mostert, Marco. A Bibliography of Works on Medieval Communication. Turnhout: Brepols, 2012.

Mullins, Daniel Austin, Daniel Hoyer, Christina Collins, Thomas Currie, Kevin Feeney, Pieter François, Patrick E. Savage, Harvey Whitehouse, and Peter Turchin. "A Systematic Assessment of 'Axial Age' Proposals Using Global Comparative Historical Evidence." American Sociological Review 83 (2018): 596-626.

Myrdal, Janken. "Agricultural Literature in Eurasia before 1500-India Compared with Islamic Countries and China." Asian Agri-History 18 (2014): 390-93.

—. Agricultural Literature in Eurasia circa 200 BCE-1500 CE. Stockholm Papers in Economic History no. 15, 2014. https://swopec.hhs.se/suekhi.

_. "Agricultural Literature in Scandinavia and Anglo-Saxon Countries c. 17001800 as an Indicator of a Deep Going Economic Enlightenment." In Knowledge Networks in Rural Europe: Historiographies, Concepts and Theories, edited by Y. Segers and L Van Molle, forthcoming.

—. Boskapsskötseln under medeltiden. Stockholm: Nordiska museet, 2012.

—. Medeltidens åkerbruk. Stockholm: Nordiska museet, 1986.

__. "On Source Criticism in World History." In Methods in World History: A Critical Approach, edited by Arne Jarrick, Janken Myrdal, and Maria Wallenberg Bondesson, 45-83. Lund: Nordic Academic Press, 2016.

Myrdal, Janken, and Alexandra Sapoznik. "Technology, Labour, and Productivity Potential in Peasant Agriculture: England, c. 1000 to 1348." Agricultural History Review 65 (2017): 194-212.

Needham, Joseph. Science and Civilisation in China, vol. 1: Introductory Orientations. Cambridge: Cambridge University Press, 1954.

Nene, Y. L. "Agriculture in General." In Krishi-Parashara: Agriculture by Parashara, translated by Nailini Sadhale, 81-94. Secunderabad: Asian Agri-History Foundation, 1999.

—. "Commentary." In Kashyapiyakrishisukti: A Treatise on Agriculture by Kashyapa, translated by S. M. Ayachit, 132-47. Secunderabad: Asian AgriHistory Foundation, 2002.

__. "Final Comments." Asian Agri-History 18 (2014): 393-94. 
—. "Foreword." In Nuskha dar Fanni-Falahat, translated by Razia Akbar, v-x. Secunderabad: Asian Agri-History Foundation, 2000.

_.."Response to Comments on Ancient and Medieval Agriculture in India." Asian Agri-History 18 (2014): 383-90.

Nuskha dar Fanni-Falahat. Translated by Razia Akbar. Secunderabad: Asian AgriHistory Foundation, 2000.

Ong, Walter J. Orality and Literacy: The Technologizing of the World. London: Methuen, 1982.

Oschinsky, Dorothea. Walter of Henley and Other Treatises on Estate Management and Accounting. Oxford: Clarendon, 1971.

Palladius. Opus Agriculturae: The Work of Farming. Translated by John G. Ficht. Blackawton: Prospect, 2013.

Parashara. Krsi-Parashara. Translated by Girija Prasanna Majumdar and Sures Chandra Banerji. Kolkata: Asiatic Society, 1960.

- Krishi-Parashara: Agriculture by Parashara. Translated by Nailini Sadhale. Secunderabad: Asian Agri-History Foundation, 1999.

Pliny. Natural History. Translated by H. Rackham. Cambridge: Harvard University Press, 1938-52.

Pollock, Sheldon. The Language of the Gods in the World of Men: Sanskrit, Culture, and Power in Premodern India. Berkeley: University of California Press, 2006.

Pomeranz, Kenneth. The Great Divergence: China, Europa, and the Making of the Modern World Economy. Princeton: Princeton University Press, 2000.

Raghvan, D., ed. Agriculture in Ancient India. New Delhi: Indian Council of Agricultural Research, 1964.

Randhawa, M. S. A History of Agriculture in India, vol. 1. New Delhi: Indian Council of Agricultural Research, 1980.

Rodrigues, Ana Duarte. "Gardening Knowledge through the Circulation of Agricultural Treatises in Portugal from the Sixteenth to Eighteenth Centuries." In Gardens, Knowledge and the Sciences in the Early Modern Period, edited by Hubertus Fischer, Volker R. Remmert, and Joachim Wolschke-Bulmahn, 305-17. Basel: Birkhäuser, 2016.

Ruymbeke, Christine van. Science and Poetry in Medieval Persia: The Botany of Nizami's "Khamsa." Cambridge: Cambridge University Press, 2007.

Sezgin, Fuat. Geschichte des arabischen Schrifttums, vol. 4: Alchimie, Chemie, Botanik, Agrikultur bis ca. 430 H. Leiden: Brill, 1971.

Schreiner, Peter. "Landwirtschaftliche Literatur (Byzanz)." In Lexikon des Mittelalters, vol. 5, 1683. Munich: DTV, 1999.

Shih Sheng-han. On "Fan Shêng-Chih Shu": An Agriculturist Book of China Written by Fan Shêng-Chih in the First Century B.C. Peking: Science, 1959. 
- A Preliminary Survey of the Book Ch'i Min Yao Shu: An Agricultural Encyclopaedia of the 6th Century. Peking: Science, 1962.

Sigaut, François. Comment Homo devient faber. Comment l'outil fit l'homme. Paris: CNRS, 2012.

Skocpol, Theda. "Emerging Agendas and Recurrent Strategies in Historical Sociology." In Vision and Method in Historical Sociology, edited by Theda Skocpol, 356-91. Cambridge: Cambridge University Press, 1984.

Smith, Thomas C. The Agrarian Origins of Modern Japan. Stanford: Stanford University Press, 1959.

Subtelny, Maria Eva. "Agriculture and the Timurid Chahārbāgh: The Evidence from a Medieval Persian Agricultural Manual." In Gardens in the Time of the Great Muslim Empires: Theory and Design, edited by Attilio Petruccioli, 110-28. Leiden: Brill, 1997.

—. "A Medieval Persian Agricultural Manual in Context: The Irshād al-zirā'a in Late Timurid and Early Safavid Khorasan." Studia Iranica 22 (1993): 13-217.

—. "Mīrak-i Sayyid Ghiyās and the Timurid Tradition of Landscape Architecture: Further Notes to a Medieval Persian Agricultural Manual in Context." Studia Iranica 24 (1995): 19-60.

Sung Ying-hsing. Chinese Technology in the Seventeenth Century: T'ien-kung k'ai-wu. Translated by E-tu Zen Sun and Shiou-chuan Sun. University Park: Pennsylvania State University Press, 1966.

Symes, Carol. "The Appearance of Early Vernacular Plays: Forms, Functions, and the Future of Medieval Theater." Speculum 77 (2002): 778-831.

—_. "Introducing the Medieval Globe." The Medieval Globe 1 (2014): 1-8.

Tauer, Felix. "Persian Learned Literature from Its Beginnings up to the End of the 18th Century." In History of Iranian Literature, edited by Jan Rypka, 479-82. Dordrecht: Reidel, 1968.

Thapar, Romila. The Penguin History of Early India: From the Origins to AD 1300. London: Penguin, 2002.

Utas, Bo. “'Genres' in Persian Literature 900-1900.” In Literary History: Towards a Global Perspective, vol. 2: Literary Genres, edited by Gunilla Lindberg-Wada, 199-241. Berlin: de Gruyter, 2006.

van Zanden, J. L. The Long Road to the Industrial Revolution: The European Economy in a Global Perspective, 1000-1800. Leiden: Brill, 2009.

Varisco, Daniel Martin. Medieval Agriculture and Islamic Science: The Almanac of a Yemeni Sultan. Seattle: University of Washington Press, 1994.

Varro: see Cato

Vesel, Živa. “Les Traités d'agriculture en Iran.” Studia Iranica 15 (1986): 99-108.

Virgil [Vergilius Maro, Publius]. Virgil. 1, Eclogues; Georgics; Aeneid I-VI. Cambridge: Harvard University Press, 1999. 
Vollman, B. D. "Einleitung." In Crescentiis, Erfolgreiche Landwirtschaft: Ein mittelalterliches Lehrbuch, Vol. 1, translated by Benedikt Konrad Vollman, 1-9. Stuttgart: Hiersemann, 2007.

Watson, Andrew. Agricultural Innovation in the Early Islamic World: The Diffusion of Crops and Farm Techniques, 700-1100. Cambridge: Cambridge University Press, 1983.

—. "Arab and European Agriculture in the Middle Ages: A Case of Restricted Diffusion." In Agriculture in the Middle Ages: Technology, Practice and Representation, edited by Del Sweeny, 62-75. Philadelphia: University of Pennsylvania Press, 1995.

White, Kenneth Douglas. Roman Farming. London: Thames and Hudson, 1970.

Wikipedia. "Arab Agricultural Revolution." https://en.wikipedia.org/wiki/Arab_ Agricultural_Revolution.

Wilkinson, Endymion Porter. Chinese History: A New Manual. Cambridge: Harvard University Asia Center, 2012.

Wojtilla, Gyula. "Introduction." In Kashyapiyakrishisukti: A Sanskrit Work on Agriculture, edited and translated by Gyula Wojtilla, 1-28. Wiesbaden: Harrassowitz, 2010.

Xenophon. Memorabilia. CEconomicus. Translated by 0. J. Todd. Cambridge: Harvard University Press, 1979.

Zadoks, Jan C. Crop Protection in Medieval Agriculture: Studies in Pre-Modern Organic Agriculture. Leiden: Sidestone, 2013. 
Janken Myrdal (janken.myrdal@ekohist.su.se) is Emeritus Professor of Agrarian History at the Swedish University of Agricultural Sciences and is currently affiliated with the Department of Economic History and the Centre for Medieval Studies at Stockholm University. His early works focused on medieval peasants and he has written extensively on the history of agrarian technology. He later went on to study the Swedish rural economy in the sixteenth century and he has also worked on the cultural history of medieval Europe and the history of everyday life through the study of miracle stories, proverbs, and religious imagery. Research on later periods includes a project on peasant diaries. In recent years, he has resumed studying medieval manuscripts and is also pursuing a project on world agricultural systems. He was the main editor of the five-volume agrarian history of Sweden, published from 1998-2003, which is available in an abridged English translation as The Agrarian History of Sweden (2011).

Abstract This article analyzes all extant agricultural treatises produced before the sixteenth century throughout Eurasia, in order to highlight their importance for the study of agricultural praxis, their significance for constructing a transnational intellectual history of the medieval globe, and their relevance for the development of pragmatic literacies. Such texts emerged both in China and around the Mediterranean before $200 \mathrm{BCE}$, and somewhat later in India, but few have been preserved and many are difficult to date. Thereafter, the medieval transmission of agricultural knowledge moved via several different regional trajectories and traditions, with Anglo-Norman England becoming a fourth and largely independent birthplace of the agricultural treatise genre during the thirteenth century. The proliferation of these texts becomes evident throughout Eurasia around 1000 $\mathrm{CE}$ and increases further from the fourteenth onward. Throughout this longue durée, the contents of these treatises reflect real changes in agricultural technologies, dominant crops, and climate.

Keywords intellectual history, economic history, agriculture, agricultural treatises, Roman Empire, Byzantium, Islamic world, China, India, medieval Europe, England, pragmatic literacy, manuscript studies, history of the book. 
Appendix

\section{THE MAJOR AGRICULTURAL TREATISES OF PREMODERN EURASIA}

The regional and chronological entries below consist of (approximate) dates, authors (when known), conventional titles, language, place of origin or publication, approximate length of text devoted to agriculture (in words or Chinese characters), and an indication of known translations into modern English $(\sqrt{ })$ if not otherwise stated. (A preliminary version of the list has been published online: Myrdal, Agricultural Literature in Eurasia. I have since made several additions and amendments.)

The spelling of proper names has been determined by the scholars cited in the bibliography. Note: not all works listed here are discussed in the accompanying article. For translations of the Chinese titles, see Bray, Science and Civilization, and for the Arabic titles see www.filaha.org/.

The word count is based in translations into modern English, and otherwise to major European languages (French, Spanish, German), because they give a similar result regarding the number of words. For one treatise the number of words in Persian has been counted. For the Chinese treatises, the number of characters has been presented by scholars, but in translations to modern English the number of words is normally ca. 50-60 percent higher than the number of characters. 


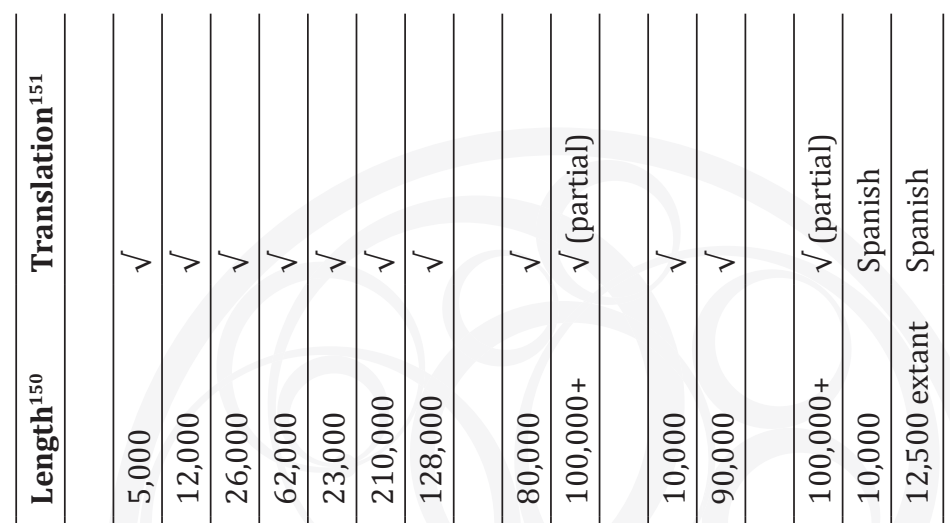

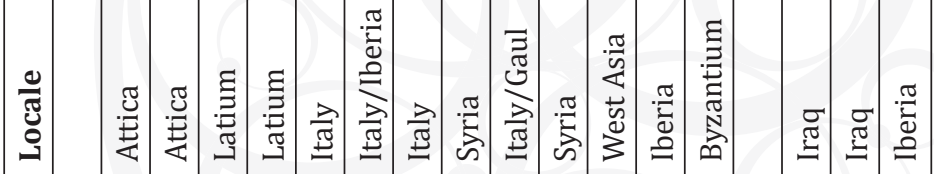

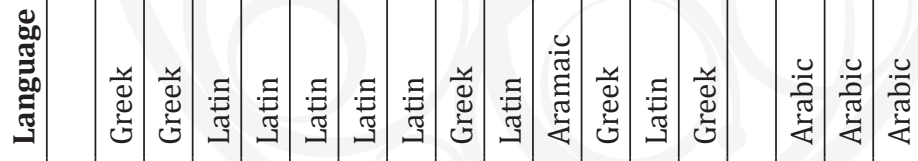

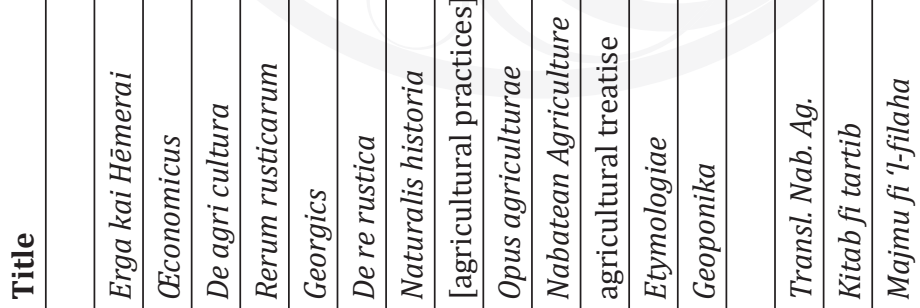

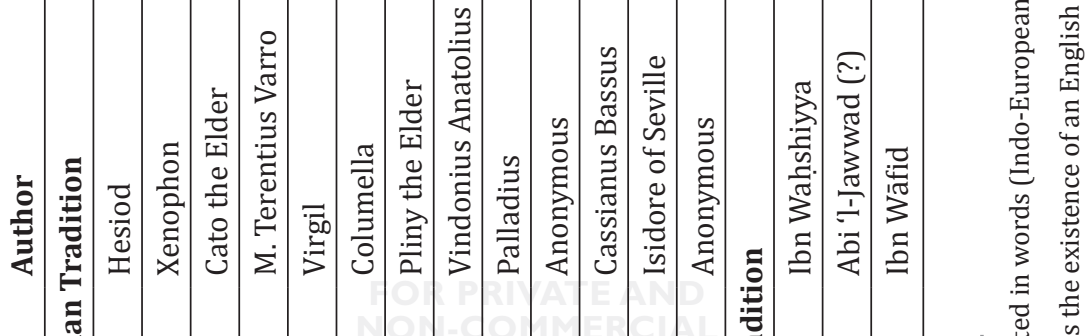

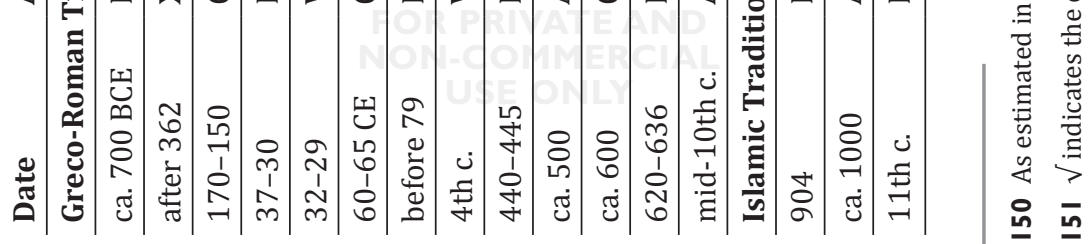




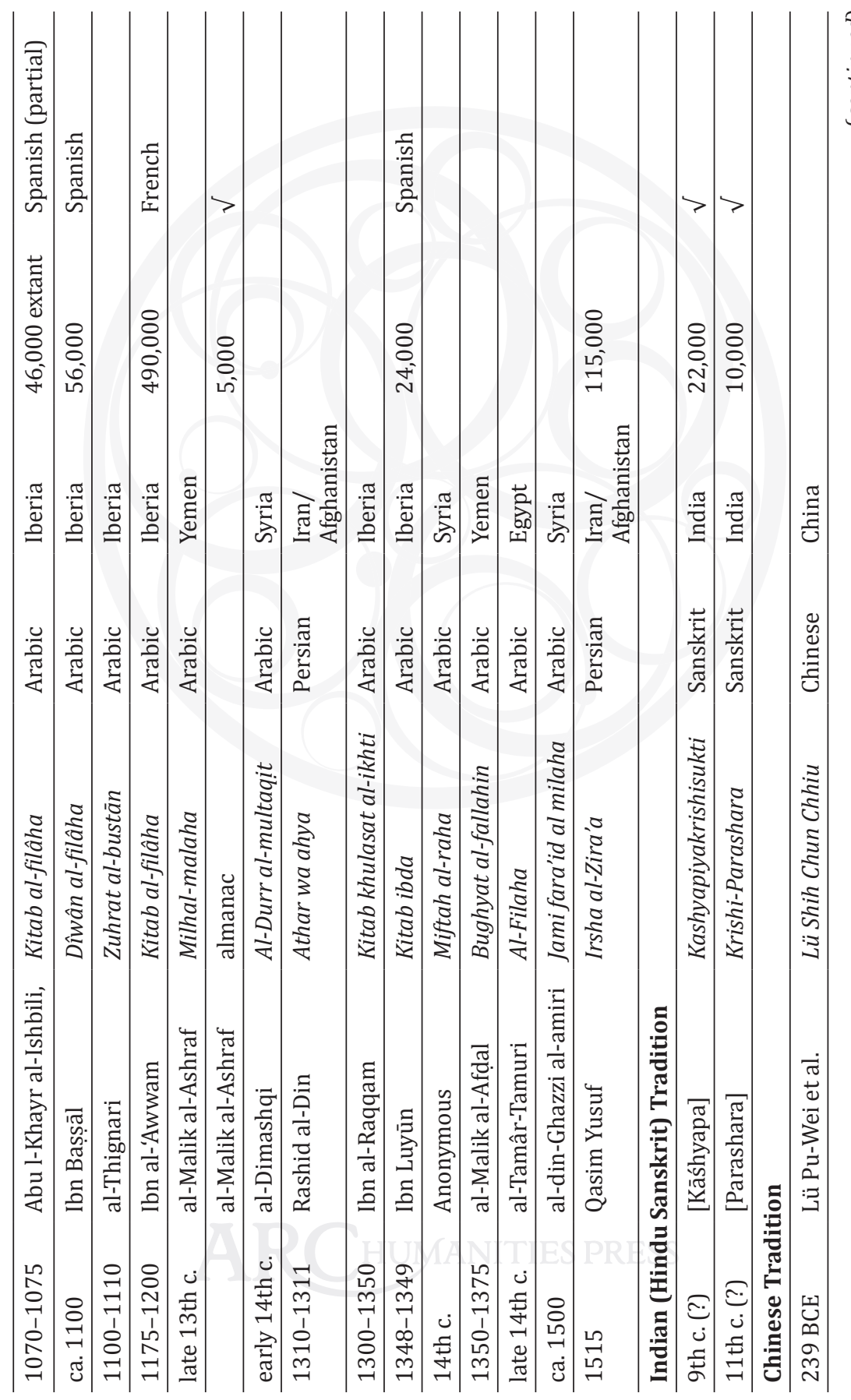




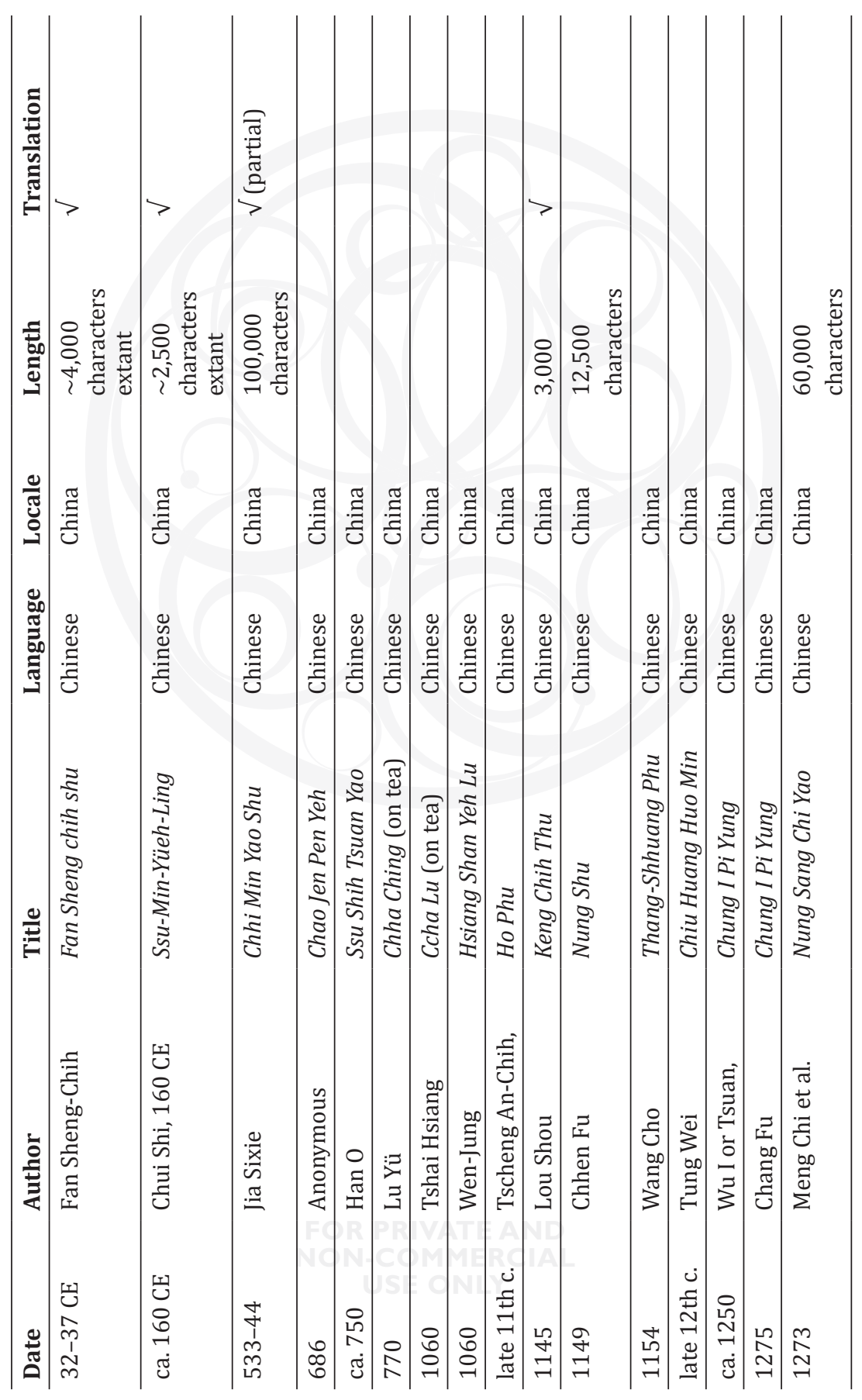




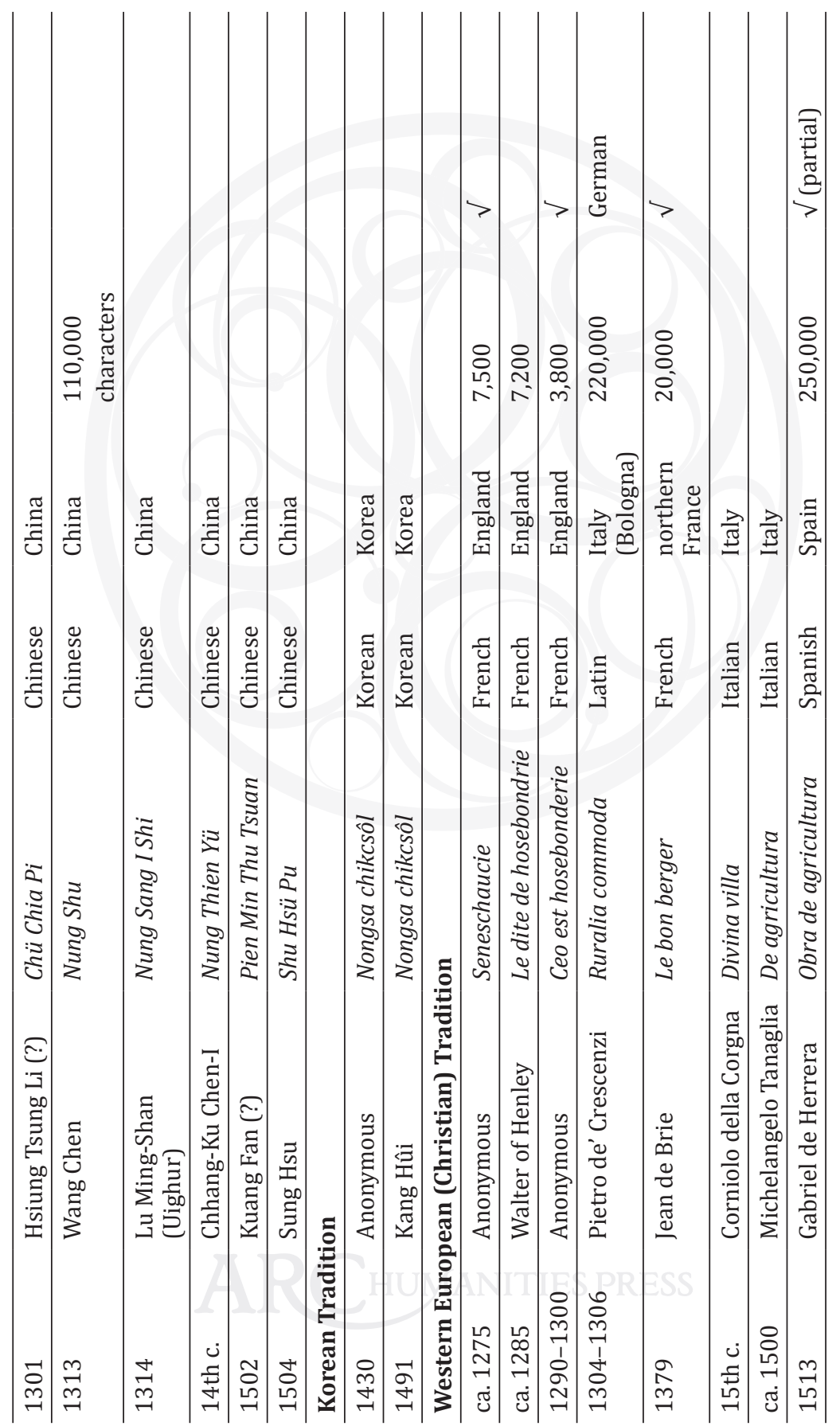




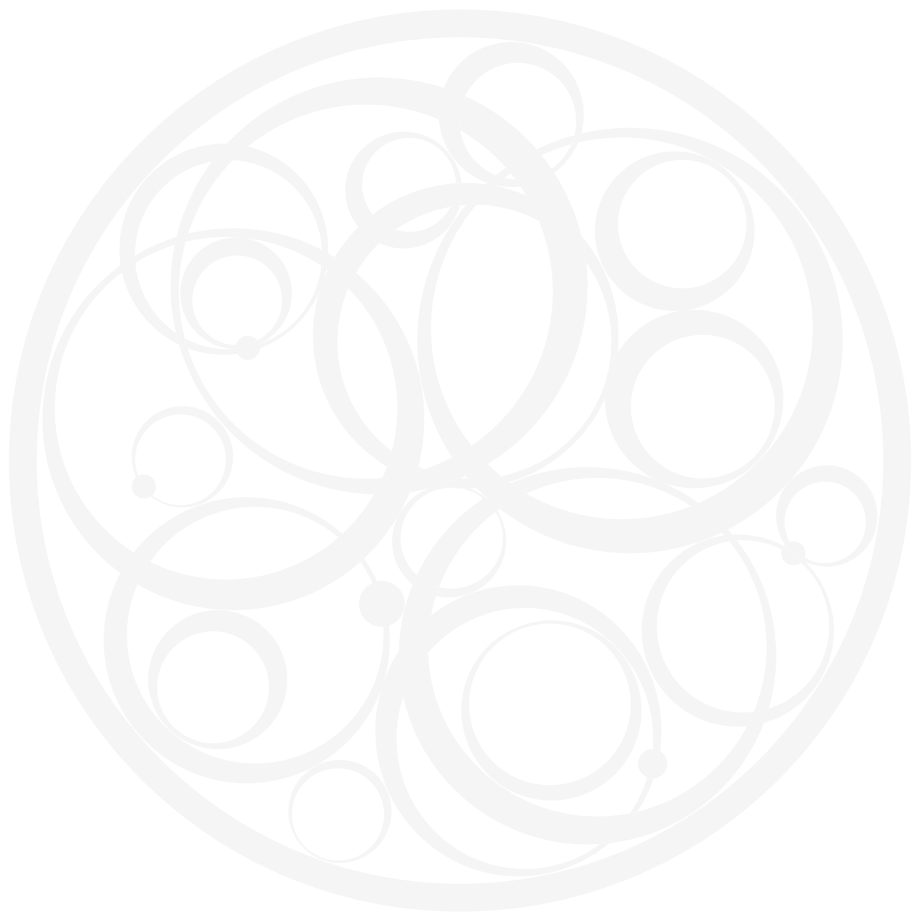

FOR PRIVATE AND

NON-COMMERCIAL USE ONLY 